\title{
How do governments actually use environmental taxes?
}

\section{Isabelle Cadoret , Emma Galli \& Fabio Padovano}

To cite this article: Isabelle Cadoret, Emma Galli \& Fabio Padovano (2020): How do governments actually use environmental taxes?, Applied Economics, DOI: 10.1080/00036846.2020.1761536

To link to this article: https://doi.org/10.1080/00036846.2020.1761536

\section{Published online: 11 Jun 2020.}

Submit your article to this journal

Џll Article views: 6

Q View related articles

View Crossmark data $\nearrow$ 


\title{
How do governments actually use environmental taxes?
}

\author{
Isabelle Cadoret (iD) ${ }^{\mathrm{a}}$, Emma Gallib and Fabio Padovano ${ }^{\mathrm{a}, \mathrm{c}}$ \\ aUniversité Rennes, CNRS, CREM UMR 6211, Condorcet Center for Political Economy, Rennes, France; biSSE, Sapienza University of Rome, \\ Rome, Italy; 'DSP, Università Roma Tre, Roma, Italy
}

\section{ABSTRACT}

This paper empirically examines how governments actually use environmental taxes, by looking to what extent their resort to this type of taxation is consistent with three alternative interpretations of environmental taxes proposed by the welfare economics theoretical literature: the strict and the broad Pigouvian and the double dividend hypotheses. We also extend our analysis to an alternative vision of politics, the Leviathan model, to verify how governments that are imperfectly accountable use environmental taxes. Each theory leads to alternative testable hypotheses, which we verify on a sample that minimizes the analysts' discretionary evaluations, the EU-28 countries that committed themselves to reducing the greenhouse gas emissions by 2020 . The estimates lend support to the strict Pigouvian hypothesis and, to a lesser extent, to a version of the double dividend hypothesis, where personal income taxes are 'recycled' by environmental ones. The other interpretations do not appear consistent with the data.

\section{KEYWORDS}

Environmental taxes; environmental policy goals; pigouvian taxation; double dividend hypothesis; leviathan government

\section{JEL CLASSIFICATION} codes: Q28; H54; H87; D72; D73; D78

\section{Introduction ${ }^{1}$}

This paper empirically analyzes how governments actually use environmental taxes (henceforth, ET), in particular to what extent theories about environmental taxation guide governments' environmental fiscal policies.

We try to answer these research questions in the context of the sample of the $28 \mathrm{EU}$ countries that in 2009 formally committed themselves to attaining a specific environmental protection target: the reduction of Green House Gases (henceafter, GHG). Two features make this sample especially suitable for our analysis. First, GHG reduction is a clearly measurable objective, as the member countries have engaged themselves to collectively reducing such emissions to $70 \%$ of the 1990 levels by 2020 . $^{2}$ Second, these countries have chosen both their collective and their country-specific reduction targets themselves. Both features reduce to a strict minimum the analysts' discretion in the evaluation of the governments' use of ET; this is at the same time a quite desirable and difficult to find feature among the other studies in the empirical literature about environmental policy, where it is usually the analyst, not the governments under study, who subjectively selects the policy goal and its degree of attainment.

The surveys of the theoretical literature on environmental taxation (Baumol and Oates 1988; Oates and Portney 2003; Sandmo 2000, 2010; OECD 2011; Bovenberg and Goulder 2002) identify four alternative theoretical underpinnings to rationalize governments' resort to ET. Three of them presuppose a benevolent government that maximizes social welfare, while the fourth one, the Leviathan model,

CONTACT Isabelle Cadoret isabelle.cadoret@univ-rennes1.fr E Università Rennes, CNRS, CREM UMR6211, Condorcet Center for Political Economy, 35000 Rennes, France

${ }^{1}$ Paper presented at the EPCS 2016 conference in Freiburg (Germany), the 2017 conference in Budapest, the 2016 EALE conference in Bologna, the TEPP Conference at La Réunion, the 2019 SIEP conference in Turin and the 2019 conference of the AISRE in L'Aquila. We thank the participants to the conferences mentioned above, Nicolas Gavoille, Benoit Le-Maux and Yvon Rocaboy as well as an anonymous referee for helpful comments on previous versions of this paper. The usual caveat applies. Corresponding author: Isabelle Cadoret. email: isabelle.cadoret@univ-rennes1.fr. I thank Sapienza University of Rome for inviting me as a visiting professor in 2015.

${ }^{2}$ Article 2.1 of decision $406 / 2009$ defines the GHG emissions as ' $\ldots$ the emission of carbon dioxide $\left(\mathrm{CO}_{2}\right)$, methane $\left(\mathrm{CH}_{4}\right)$, nitrous oxide $\left(\mathrm{N}_{2} \mathrm{O}\right)$, hydrofluorocarbons (HFCs), perfluorocarbons (PFCs) and sulphur hexafluoride $\left(\mathrm{SF}_{6}\right)$, , ...] expressed in terms of tons of carbon dioxide equivalent'. The same decision commits the EU member countries collectively to reduce GHG to $70 \%$ of their 1990 levels by the year 2020. In addition to this EU wide target, the Decision sets also country-specific targets, to account for the economic and environmental starting point situations of each country, especially those of the former Eastern European nations. (Annexe II to Decision 4006/2009). Furthermore, the EU member states' targets are given by the EU Effort Sharing Decision where 'Member States' reduction efforts should be based on the principle of solidarity between Member States [...] taking into account the relative per capita GDP of Member States'. Furthermore, the national 2020 targets apply to non-Exchange Trade System emissions, a crucial fact, since it allows analysing the impact of ET in reducing a type of emissions and in sectors where an important policy instrument, such as ETS, do not operate (preliminary n. 6 of decision 406/2009).

(c) 2020 Informa UK Limited, trading as Taylor \& Francis Group 
assumes that governments maximize tax revenues. This alternative approach is useful to verify how an imperfectly accountable government may use ET. In policy terms, these four categories identify as many ways to employ ET revenues in the correction of the environmental externality. The first is the classical Pigouvian interpretation, whereby ET are sufficient to internalize negative environmental spillovers, provided that the rates are correlated with the externality in a first or second best way. In this 'strict' conception of the Pigouvian tax the revenues generated must not be reinvested in the correction of that externality, to avoid further distortions (Baumol and Oates 1988; Jacobs and de Mooij 2015; Cremer, Gahvari, and Ladoux 1998). A second, looser version of this hypothesis, which stems from the public policy literature (Fouquet and Johanson 2008; Kosonen and Nicodème 2009; OECD 2011; Hoerner and Bosquet 2001; Sterner and Isaksson 2006) and from recent contributions to the literature on environmental tax reform (Acemoglu et al. 2012; Bovenberg, Goulder, and Jacobsen 2008; Gersbach and Requate 2004) holds that the complexity of environmental policies requires that ET be jointly used with other environmental policy instruments, including the revenues from ET, which should be reinvested in pursuit of environmental goals. As this interpretation relaxes a binding constraint in the use of revenues from ET, we label it 'broad Pigouvian'. A third set of studies, often associated with earlier contributions to the environmental tax reform literature, suggest that ET revenues can be used to achieve a 'double-dividend'; one from the correction of the environmental externality, the other from the substitution of ET to other taxes with larger excess burdens, chiefly the personal income tax. Under certain conditions, such a 'recycling of tax instruments' would increase both social welfare and the overall efficiency of the economy (Bovenberg and De Mooij 1994; Goulder 1995; EC 2011; Parry 1998; Lai 2009; Bento and Jacobsen, 2007; Bosquet 2000; Schöb 2003). A common assumption to these three strands of literature is that governments maximize a social welfare function; yet the public choice literature proposes an alternative vision of government, the Leviathan model, which maximizes revenues instead of social welfare. This change of objective function allows to formulate a fourth alternative hypothesis about how governments use ET, which is especially insightful for situations where governments' electoral accountability is imperfect (Kirchgassner and Schneider 2003; Congleton 1992; Morse 2006; Fredriksson and Svensson 2003). A Leviathan government exploits the fact that ET are the least unpopular of all fiscal levies, because of the citizens' favourable outlook on the protection of the environment (EU Commission, 2014; Thalmann 2004), to maximize tax revenues at the lowest political cost. Governments would therefore insist in their resorting to ET, irrespective of the efficiency at achieving environmental goals; moreover, they would redistribute ET revenues to secure a power base and/or maximize electoral support (Aidt 1998, 2010; Fredriksson and Sterner 2005; Duit, Feindt, and Meadowcroft 2016).

Our strategy consists in successively testing the empirical restrictions that the theoretical literature associates to each of these alternative interpretations of ET, to check which one is best supported by the data. To verify the strict Pigouvian hypothesis, we compare the intensity with which each country resorted to ET to their success in achieving the GHG reduction target. A positive correlation between the country's relative distance from the target and its use of ET confirms that ET are adopted to (and effective at) correcting the negative environmental externality, because if ET reduce the observed emissions the difference increases. Table 1 provides a description of the variable. For the broad Pigouvian interpretation, which insists on the consistency in the use of taxing and spending instruments in environmental policy, we check the baseline requirement that countries that resort to ET more also spend more for the general protection of the environment. As for the double dividend hypothesis, we verify whether countries actually substitute ET to personal income taxation (or to other revenue sources), to reduce the distortionary effects of high marginal tax rates. Finally, we directly test the Leviathan hypothesis, by verifying whether ET revenues are positively correlated to expenditure programmes with a high redistributive and vote-buying potential.

This type of analysis faces two fundamental difficulties, which the empirical literature has failed to address so far. The first is that the distance from the environmental target can be either negative or positive. As Figure 1 shows, countries may either fall short 
Table 1. Description of the variables.

\begin{tabular}{|c|c|c|}
\hline Name & Definitions and units & Source \\
\hline GHG & Greenhouse gas emissions in Effort Sharing Decision (ESD) sectors - million tons of $\mathrm{CO}_{2}$ equivalent & Eurostat \\
\hline TARGET & $\begin{array}{l}\text { EU Commission decision 2017/1471 of } 10 \text { August 2017, modifying decision 2013/162/UE aiming at revising the } \\
\text { yearly allocations of the emission quotas of member States for the 2017-2020 period }\end{array}$ & \\
\hline GHG_DIFF & (Target - GHG observed)/GHG observed & Own calculations \\
\hline ET_REV & $\begin{array}{l}\text { Total environmental taxes as percentage of total revenues from taxes and social contributions (including imputed } \\
\text { social contributions) }\end{array}$ & Eurostat \\
\hline OTHER_REV & $\begin{array}{l}\text { Total receipts from taxes and social contributions (including imputed social contributions) after deduction of } \\
\text { amounts assessed but unlikely to be collected minus environmental tax revenues as \% of GDP }\end{array}$ & Eurostat \\
\hline ET_RATE & $\begin{array}{l}\text { Variation of the ratio between energy tax revenues and final energy consumption calculated for a calendar year. } \\
\text { Energy tax revenues are measured in euro } 2010 \text { (deflated with the gross market product implicit deflator) and the } \\
\text { final energy consumption in TOE (tons of oil equivalent), therefore the ITR on energy is measured in EUR per TOE. }\end{array}$ & Eurostat \\
\hline ENV_EXP & Total general government expenditure for environmental protection as a percentage of GDP & Eurostat \\
\hline GS_EXP & $\begin{array}{l}\text { Total general government expenditure for general public services as a percentage of GDP. This item includes general } \\
\text { transfers between different government levels for government services, general public services, basic research, } \\
\text { general services }\end{array}$ & Eurostat \\
\hline SC_EXP & $\begin{array}{l}\text { Total general government expenditure for social protection as a percentage of GDP. This item includes aid for } \\
\text { sickness and disability, family and children, old age, unemployment, survivors, housing, social exclusion and social } \\
\text { protection. }\end{array}$ & Eurostat \\
\hline DEBT & Government consolidated gross debt as percentage of GDP & Eurostat \\
\hline ENERGY_INT & $\begin{array}{l}\text { Energy intensity of GDP in purchasing power standards (PPS), Kilograms of oil equivalent (KGOE) per thousand euro } \\
\text { in purchasing power standards (PPS) }\end{array}$ & Eurostat \\
\hline ENERGY_DEP & Energy dependence, net imports divided by the sum of gross inland energy consumption plus bunkers \% & Eurostat \\
\hline G_GDP_PC & Annual growth rate of GDP per capita, PPP (constant 2011 international US\$) & World Bank WDI \\
\hline GDP_PC & GDP per capita, PPP (constant 2011 international US\$) & World Bank WDI \\
\hline MARTAX & Income Tax, Top statutory personal income tax rates & OECD \\
\hline RLE & $\begin{array}{l}\text { Rule of law, composite measures of governance in units of a standard normal distribution, with mean zero, standard } \\
\text { deviation of one, and running from approximately }-2.5 \text { to } 2.5\end{array}$ & World Bank WGI \\
\hline VA_IND & Industry, value added (\% of GDP) & World Bank WDI \\
\hline
\end{tabular}

of their target, and therefore be supposed to intensify their environmental policies; or they may go beyond it and may in principle relax their fiscal efforts. To account for this difference, we distinguish between countries with a positive difference with respect to the target, i.e., those that have already achieved or even done better than it, from those with a negative difference, i.e., those which still have to attain their target.

The second problem is the choice of the proper fiscal indicator to measure the effects of ET. The theoretical literature is not univocal in this respect. Strict Pigouvian models advise using ET rates as the policy choice variable (Baumol and Oates 1988; Sandmo 2010). Revenue-based measures of fiscal effort, such as the ratio of ET revenues over total tax revenues, seem instead more appropriate for the other three explanations (Schöb 2003). In particular, the ET's efficiency at correcting the externality also affects the choice between either a rate-based or a revenue-based indicator of the government's effort at reducing the externality. If governments actually use ET in a Pigouvian way and these taxes are effective at reducing GHG emissions, we should observe in those countries higher marginal ET rates but lower ET revenues than the sample average, since the high tax rates reduce the externality and the revenue source with it. Yet, if ETs are inefficient at correcting the externality and governments still acted in a Pigouvian way, the revenue source would still exist, so that both marginal rates and revenues should be higher than the sample average. To sort out this problem, we estimate the model using proxies for both ET rates and revenues. Figures 2 and 3 illustrate the average values of these two indicators of environmental fiscal efforts in the chosen sample. According to Eurostat, our data source, ' $\ldots$ an environmental tax is a tax whose base is a physical unit (or a proxy of a physical unit) of something that has a proven, specific negative impact on the environment'. ET then fall within the following economic sectors: energy, transport, pollution, water resources.

Furthermore, as the two alternative visions of government (welfare vs. revenue maximizing) imply categorically different uses of ET, one must control for the politico-institutional environment in which ET policies are decided and implemented. The positive political economy literature concurs that the redistributive effects between producers and consumers/voters that ET generate are a good indicator of the goals that governments pursue in their environmental policies. Governments in fact tilt such redistribution in favour of either group according to their electoral vs. lobbying accountability, which depends on the political and 


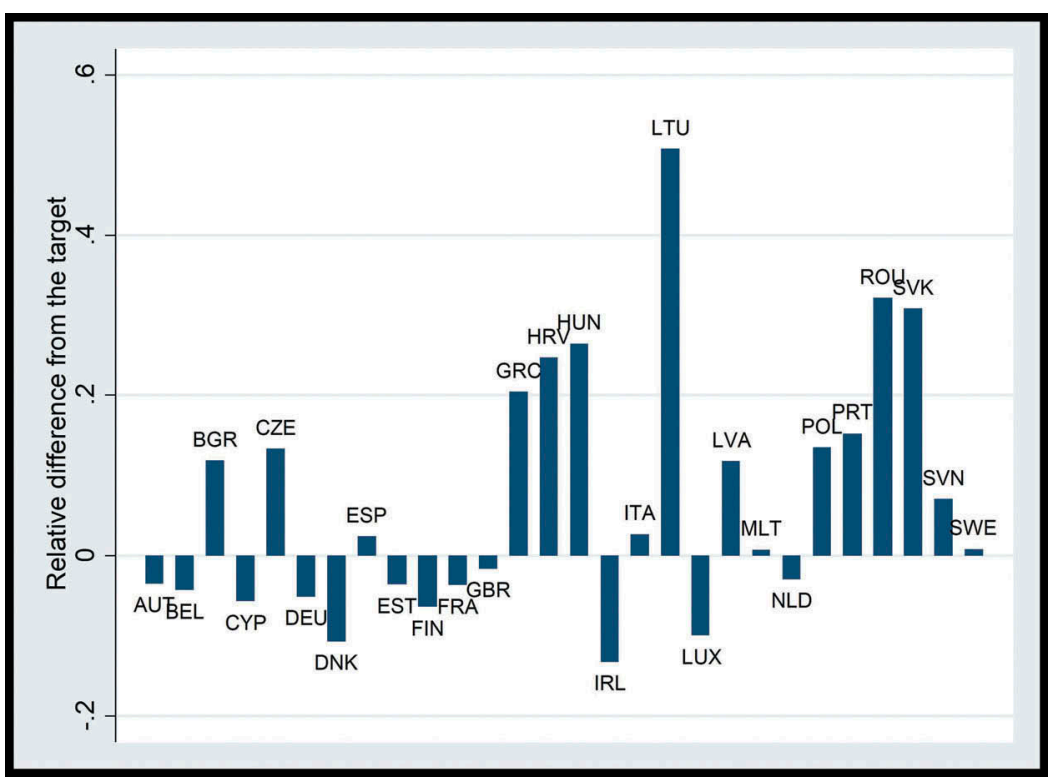

Figure 1. Mean over the period of the relative difference of GHG emissions from the target (Target - observed GHG)/Target.

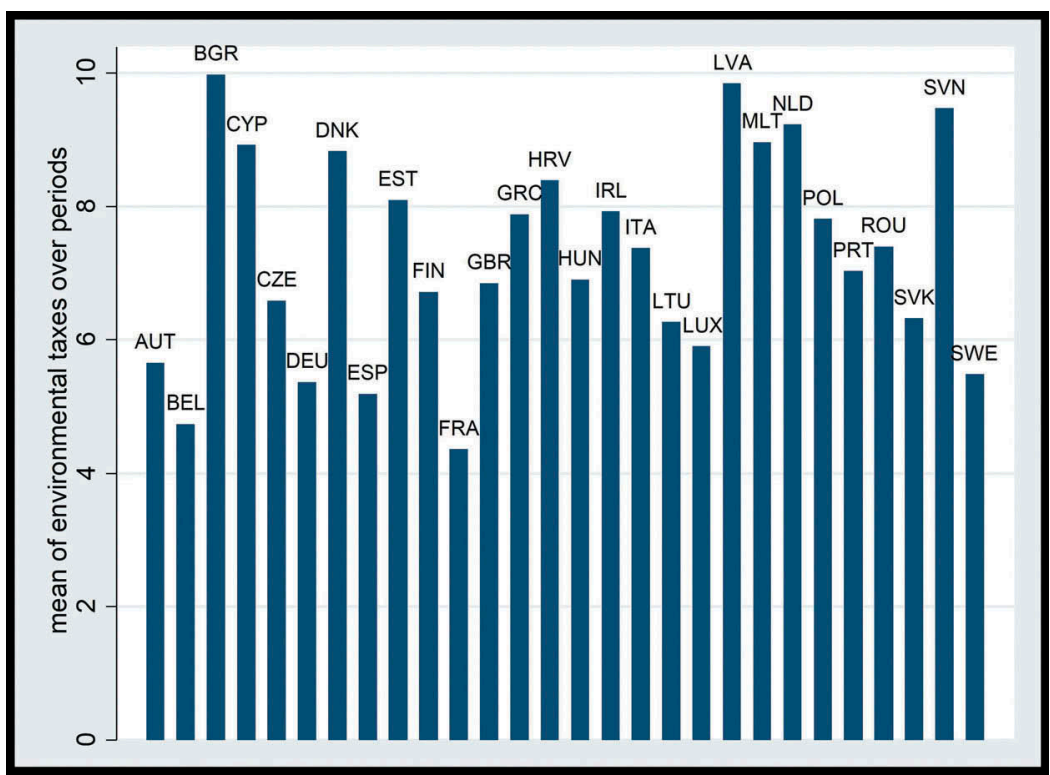

Figure 2. Total revenues from environmental taxes as a percentage of total revenues from taxes and social contributions (including imputed social contributions).

institutional framework where environmental policy decisions are taken (Cadoret and Padovano 2019; Polk and Schmutzler 2005; Fredriksson and Sterner 2005; Kirchgassner and Schneider 2003; Aidt 1998, 2010). Controlling for these variables allows also to assess in which institutional environment ET function better (Congleton, 2002). Naturally, countries dispose of other policy instruments that can be adopted to achieve environmental goals, like regulation, the creation of markets and so on. We control for them through the country fixed effects, since regulation and other non-fiscal environmental policies tend to remain stable features of each country over time (OECD 2011; Botta and Kozluk, 2014).

The rest of the paper is organized as follows. Section 2 illustrates the empirical strategy, the dataset and the specification of the model. The results of the estimates about the strict Pigouvian hypothesis are discussed in section 3 . In section 4 we verify the broad Pigouvian interpretation. Section 5 examines the evidence related to the double dividend 


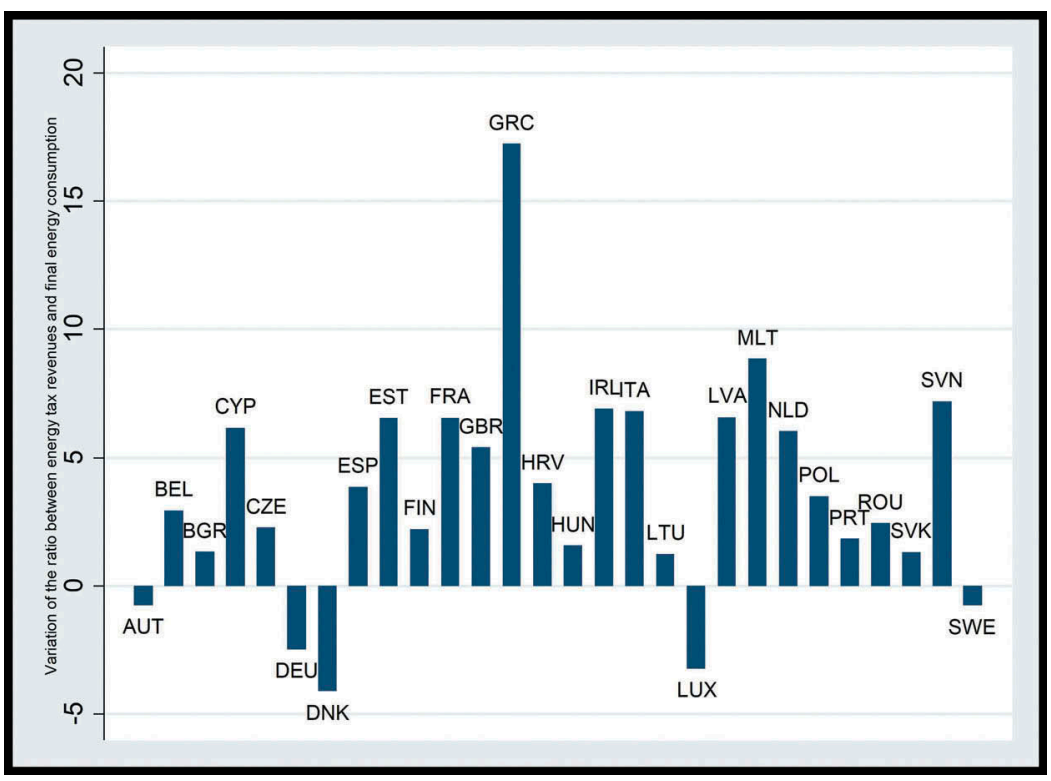

Figure 3. ET_RATE as a proxy for the effective marginal tax rate of environmental taxation.

hypothesis, while section 6 discusses the evidence supporting the Leviathan interpretation. Section 7 summarizes the conclusions of the analysis and presents its policy implications.

\section{Empirics}

\section{Empirical testing strategy}

Bringing the four theoretical hypotheses to the data first involves selecting the dependent variables, which will be regressed on the main variables of interest related to each hypothesis, plus three sets of controls: the economic variables $\mathbf{X}$, the energy characteristics and environmental policy variables $\mathbf{W}$ and the politico-institutional variables $\mathbf{Z}$. The variables included in these vectors are selected according to the relevant empirical literature, to maximize the comparability of our results with those of previous studies. All models are estimated dynamically via the Arellano-Bond GMM estimator with robust standard errors. This estimating technique has the important advantage of accounting for potential endogeneity problems. The LevinLin-Chu unit-root test confirms that all variables are stationary (Table A1 in the Appendix).

As a robustness check, we repeat the same estimates via the within estimator, examining also different explanatory variables. The results, never qualitatively different from those obtained via
Arellano-Bond GMM, are reported in the Appendix Table A2, A3, A4, A5 and A6.

Our empirical strategy proceeds in four steps, each one dealing with one of the hypotheses under test.

\section{Strict Pigouvian hypothesis}

The first step is testing the strict Pigouvian interpretation. As the endogenous variable we select the relative difference between the country's GHG emissions target and the observed emissions, normalized by observed emissions, named GHG_DIFF. We consider Greenhouse gas emissions in Effort Sharing Decision (ESD) sectors expressed in million tons $\mathrm{CO}_{2}$ equivalent. The ESD sets emission targets for member states for each year until 2020, according to Decision 406/2009 - Annexe II; targets are derived from the official source, the EU Commission Decision n. 2017/1471. Compliance with targets is reviewed every year. Normalizing the distance separating the country from the target captures the country's effort in attaining their GHG target. This variable is also separated in two groups, one including countries that are doing better than their target (usually, the Eastern European ones) and have thus a positive difference; the other with the countries that are underscoring their specific target (typically the Western Europeans ones) and show a negative difference. The specification of the empirical model is as follows: 


$$
\begin{aligned}
G_{H}{ }_{-} D I F F_{i t}= & \alpha_{1} G H G \_D I F F_{i t-1}+\beta_{1 T} \mathbf{E T}_{-} \mathbf{R} \mathbf{A T E} \mathbf{E}_{i t} \\
& +\beta_{1 R} \mathbf{E T} \_\mathbf{R E V} \mathbf{V}_{i t}+\gamma_{1} \mathbf{X}_{i t}+\delta_{1} \mathbf{W}_{i t} \\
& +\theta_{1} \mathbf{Z}_{i t}+\varphi_{i}+\epsilon_{i t}
\end{aligned}
$$

where $i$ identifies the country and $t$ the year; $\varphi$ are the country fixed effects. Since the attainment of the GHG target is progressive over time, the equation includes the lagged dependent variable. We consider the covariate ET_REV endogenous in the model, since the distance from the GHG target variable may determine the countries' resort to ET, but at the same time the use of ET may affect the countries' distance from the GHG target.

As already anticipated, the strict Pigouvian hypothesis requires examining two complementary measures of ET, the ET rates and the ET revenues. The variable ET_REV represents revenues of environmental taxes, measured as the ratio of environmental tax revenues over total fiscal revenues. ET_RATE is instead a proxy for the effective marginal incidence of environmental taxation, specified as the variation of the implicit energy tax rate calculated over two successive years (see Table 1 for the detailed description of the variable). As mentioned in the introduction, if ET are (used as) Pigouvian taxes and prove effective at reducing GHG emissions, the negative correlation between ET rates and GHG emissions should reduce the tax base for the ET. If, instead, ET are inefficient at correcting the externality, even in the case when governments acted in a Pigouvian way, the externality would still remain and the revenue source with it. In this case we should observe both high ET rates and ET revenues. We estimate the model using both ET_RATE and ET_REV as proxies for the country's environmental fiscal effort. The low correlation coefficient between the two indicators $(r=0,17)$ legitimizes the use of both as alternatives in our analysis. We hold that the strict Pigouvian hypothesis is confirmed if there is a positive correlation between GHF_DIFF and ET_RATE and a non significant one on ET_REV.

Among the economic variables of vector $\mathbf{X}$, we begin by examining the complex relationship between income-related variables and pollution. A first theoretical linkage is the well-known environmental Kuznets curve, which posits a positive relationship between economic development and environmental degradation at low levels of per capita income that turns negative when citizenstaxpayers' support for environmental protection begins to improve environmental quality (Arrow et al. 1995). Moreover, the 'green' neoclassical growth models (Ordás Criado, Valente, and Stengos 2011; Brock and Taylor 2010) show that the instantaneous growth rate of emissions per capita is negatively correlated with the level of emissions per capita (a 'defensive effect'), but positively correlated with the growth rate of output per capita (a 'scale effect'). These papers argue that combining economic growth with an increasing environmental quality requires a sufficiently high rate of emission-reducing technical progress, especially investments in pollution abatement activities. Ordás Criado, Valente, and Stengos (2011) test this hypothesis on a variety of pollutant agents in a sample of 25 European countries, but not for GHG reduction. We complement their analysis by inserting in Equation (1) both indicators of per capita economic growth (G_GDPPC) and of per capita income levels (GDP_PC) in logs, and let the sign on the latter be determined by the empirical analysis. The square of the log of GDP_PC is introduced to test for the environmental Kutznets curve.

As for the controls for energy and environmental policies of vector $\mathbf{W}$, we first consider the energy intensity in production (variable ENERGY_INT), specified as the log of the kilogram of oil equivalent per 1000 euros worth of products. The variable is introduced in logs. The expected sign on this covariate is always negative, since ENERGY_INT increase GHG emissions, reducing the value of GHG_DIFF. We have also considered the country's energy dependency rate (ENERGY_DEP), which indicates how much an economy relies on imports to meet its energy requirements. This variable is an indirect measure of the country's competitiveness, since it accounts for the weight of the imported energy on the actual costs of domestic products; as such, it should be positively correlated with the country's propensity to introduce ET. Finally, we include a linear TREND that accounts for technological progress.

The variables in vector $\mathbf{Z}$ capture how similar the country's political and institutional framework is to the Leviathan extreme case. Holding constant the covariates in vectors $\mathbf{W}$ and $\mathbf{X}$, the arguments of $\mathbf{Z}$ tell us why, for a given use of ET, some countries 
are more efficient than others at reaching their GHG target. Among the many variables that we have controlled for, those that have most consistently shown some explanatory power are RLE, an indicator of the degree of enforcement of the law in the country, from the World Bank World Governance Indicators. Greater values of RLE suggest that government decisions are more efficiently implemented, which minimizes government discretion that would instead be magnified in a Leviathan world. A second variable is VA_IND, i.e., the share of value added from industry on total GDP. This variable is commonly used in the literature to capture the influence of lobbies (Fredriksson, 2004; Cadoret and Padovano 2019). It reflects the idea that the greater is the value added of an industry, the higher are the producers' costs of coordination in order to get organized as a lobby. ${ }^{3}$ The predicted impact of VA_IND on GHG_DIFF is therefore positive, since more value added increases lobbying costs, which reduces observed GHG thus increasing GHG_DIFF.

\section{Broad Pigouvian hypothesis}

The second step of the analysis is testing the broad Pigouvian hypothesis. To this end we estimate a similar model to the one adopted for the strict Pigouvian but using the countries' expenditures for environmental protection, ENV_PROT, as a percentage of GDP, as the dependent variable. Environmental protection expenditures are the most comprehensive aggregate of government outlays for environmental purposes for which Eurostat collects information. The broad Pigouvian interpretation imposes consistency between environmental policy instruments: hence a greater resort to ET should be reflected in higher expenditures for environmental protection (Duit, Feindt, and Meadowcroft 2016; Pearce and Palmer 2001). Equation (2) is therefore specified with ET_REV as the main explanatory variable of:

$$
\begin{aligned}
E N V \_P R O T_{i t}= & \alpha_{2} E N V \_P R O T_{i t-1}+\beta_{2} E_{2} E_{-} R_{E V} V_{i t} \\
& +\gamma_{2} \mathbf{X}_{i t}+\delta_{2} \mathbf{W}_{i t}+\theta_{2} \mathbf{Z}_{i t}+\varphi_{i}+\eta_{i t}
\end{aligned}
$$

In vector $\mathbf{X}$ we have considered proxies for other revenue sources other than ET_REV that can finance environmental expenditures. To avoid problems of multicollinearity, the arguments of $\mathbf{X}$ have been included in the estimates when ET_REV was not. The first is the country's debt-to-GDP ratio, measured as the general government consolidated gross debt and labelled DEBT. On the one hand, as public debt relaxes the (contemporary) government's budget constraint, this variable should be positively correlated with total government expenditures, including those for environmental protection; on the other hand, highly indebted countries might be forced to rebalance their finances and then be forced to cut spending on the environment, which should result in a negative correlation. The sign of the coefficient is left for the empirical analysis to settle. As the service of the debt is often a non-negligible expenditure item, we consider the covariate DEBT endogenous in the model. Furthermore, we have included the nonenvironmental taxes (variable OTHER_REV), measured as the difference between total tax revenues and environmental tax revenues, normalized by GDP. As more revenues relax a binding constraint, the expected sign is positive.

\section{The double dividend hypothesis}

The third step of the analysis focuses on the double dividend hypothesis. As it is standard in the literature (Schöb 2003; Parry 1998; Goulder 1995), we verify this hypothesis by introducing a proxy for marginal tax pressure in the equation that explains the government resort to ET. The early environmental tax reform literature considered substitutions chiefly between ET and personal income taxes, as they carried the largest distortionary effects. More recent contributions to this literature have extended the policy of 'revenue recycling' also to other taxes, such as the general consumption taxes. Value added taxes, however, show a very low within variance, which makes them difficult to disentangle from the country fixed effects. We have therefore focused on the variable MARTAX, the top legislated marginal tax rate on personal income, from OECD. Equation (3) is therefore a tax setting equation for ET.

\footnotetext{
${ }^{3}$ Demania et al. (2005), Fredriksson (1997) and Conconi (2003) are among the various papers that specify lobbying power in this way. Other lobbying variables considered are MAN_VA, the share of value added from the manufacturing industry on total GDP, as well as AGR_VA, the diffusion of lobbies from the agricultural sector. They prove collinear with VA_IND.
} 


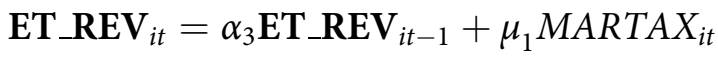

$$
\begin{aligned}
& +\beta_{1} \mathbf{X}_{i t}+\gamma_{1} \mathbf{W}_{i t}+\delta_{1} \mathbf{Z}_{i t}+\varphi_{i}+\varpi_{i t}
\end{aligned}
$$

A negative correlation between MARTAX and the ET_REV is evidence of substitution of ET for personal income taxes to reduce marginal excess burdens.

\section{Leviathan hypothesis}

Finally, for the Leviathan hypothesis our empirical strategy exploits the implication that imperfectly accountable governments maximize revenues to secure their power base at the lowest political cost. To this end, such a government should channel the ET revenues to highly redistributive expenditures, which can target specific groups, thus yielding higher political returns, as opposed to general purpose, public-good like expenditure items, which benefit the population at large in a rather undifferentiated manner (Aidt 1998, 2010; Kirchgassner and Schneider 2003). We therefore regress two quite opposite types of expenditure items, social expenditures (labelled SC_EXP) and expenditures for general services (GS_EXP) on ET revenues. Both are normalized by GDP. According to the Eurostat classification itself, social protection expenditures are the ones with the strongest redistributive profile, while general services instead are the closest proxy to the concept of public goods (see Table 1 for the disaggregation of these expenditure items). The stark difference between these expenditure items maximizes the power of our test that is undermined by the rather low share of ET over total revenues. To confirm the Leviathan hypothesis, we should find a positive correlation between ET_REV and SC_EXP, but not with GS_EXP. A lack of statistical significance on the coefficients of ET_REV on both expenditure items is instead consistent with the implication of the Pigouvian hypothesis that ET are sufficient to correct the externality, and revenues should not be targeted to any specific expenditure. We estimate the following model:

$$
\begin{aligned}
\mathbf{Y}_{i t}= & \alpha_{1} \mathbf{Y}_{i t-1}+\beta_{1} \mathbf{E T} \_\mathbf{R E V} \mathbf{V}_{\mathbf{i t}}+\gamma_{1} \mathbf{X}_{i t}+\delta_{1} \mathbf{W}_{i t} \\
& +\theta_{1} \mathbf{Z}_{i t}+\varphi_{i}+\eta_{i t}
\end{aligned}
$$

Where vector $\mathbf{Y}_{i t}$ includes SC_EXP and GS_EXP.

\section{Sample}

The sample encompasses 28 EU countries that, through Decision 406/2009, have: A) committed themselves to collectively reduce GHG to $70 \%$ of their 1990 levels by the year 2020; and B) agreed to a series of country-specific targets, to account for the economic and environmental starting points of each country, especially those of the former Eastern European nations (Benjamin et al. 2015). They are Austria, Belgium, Bulgaria, Cyprus, Croatia, Czech Republic, Denmark, Estonia, Finland, France, Germany, Greece, Hungary, Ireland, Italy, Latvia, Lithuania, Luxembourg, Malta, the Netherlands, Poland, Portugal, Romania, Slovakia, Slovenia, Spain, Sweden and the the United Kingdom. The time interval covers the period 2005-2017, for which Eurostat provides coherent data for the Greenhouse gas emissions in Effort Sharing Decision (ESD) sectors; furthermore, 2005 is the beginning year for the effort sharing policy in the attainment of the GHG target. Each variable thus features a maximum of $13^{\star} 28=364$ observations, quite enough to obtain efficient estimates. Table 1 describes the characteristics of the variables and their data sources, while Table 2 provides the descriptive statistics. Table 3-6 present the results that are pertinent to the objective of our analysis.

\section{Testing for the strict Pigouvian hypotheses}

The estimates of Equation (1) about the strict Pigouvian hypothesis are reported in Table 3.

If we consider the whole sample (models 1-2), the results appear consistent with the strict Pigouvian hypothesis in the cases where ET are effective at reducing the GHG emissions, thereby rising GHG_DIFF. Model 1 assumes ET_REV to be endogenous, but the coefficient is not statistically significant. ET_RATE has instead the expected positive sign. This pattern confirms that high marginal rates of ET actually reduce the environmental externality represented by the GHG emissions; this widens the positive gap from the GHG target for countries that have already achieved their objective, or reduces the negative one for those that still have to attain it. Such a reduction of the externality also shrinks the tax base for ET. This result is slightly more evident in the subsamples of the underachieving countries (models 
Table 2. Descriptive statistics.

\begin{tabular}{|c|c|c|c|c|c|c|c|}
\hline VARIABLES & Unit & $\mathrm{N}$ & Mean & Median & Standard deviation & Min & Max \\
\hline GHG_DIFF & relative difference & 364 & 0.0694 & .0395 & 0.167 & -0.195 & 0.707 \\
\hline ET_REV & $\%$ & 364 & 7.263 & 7.130 & 1.692 & 4.150 & 11.63 \\
\hline OTHER_REV & $\%$ & 364 & 33.79 & 32.865 & 5.715 & 21.75 & 46.13 \\
\hline ET_RATE & variation in $€ / T O E$ & 364 & 3.597 & 1.530 & 14.75 & -49.79 & 83.35 \\
\hline ENV_EXP & $\%$ & 364 & 0.763 & 0.70 & 0.341 & -0.300 & 1.900 \\
\hline GS_EXP & $\%$ & 364 & 6.393 & 6.30 & 1.897 & 2.800 & 12.90 \\
\hline SC_EXP & $\%$ & 364 & 16.40 & 16.50 & 3.906 & 7.900 & 25.60 \\
\hline DEBT & $\%$ & 364 & 60.48 & 54.50 & 34.70 & 3.700 & 178.9 \\
\hline logENERGY_INT & logarithm & 364 & 4.980 & 4.942 & 0.285 & 4.039 & 5.717 \\
\hline ENERGY_DEP & $\%$ & 364 & 56.10 & 56.485 & 26.75 & -50.92 & 104.2 \\
\hline G_GDP_PC & $\%$ & 364 & 1.728 & 1.770 & 3.920 & -14.56 & 23.94 \\
\hline logGDP_PC & logarithm & 364 & 10.37 & 10.367 & 0.371 & 9.427 & 11.49 \\
\hline MAR_TAX & $\%$ & 299 & 41.06 & 45.00 & 13.17 & 15.00 & 62.68 \\
\hline VA_IND & $\%$ & 364 & 23.46 & 23.513 & 5.868 & 9.368 & 38.52 \\
\hline RLE & {$[-2.5 ; 2.5]$} & 364 & 1.134 & 1.129 & 0.611 & -0.138 & 2.100 \\
\hline
\end{tabular}

Table 3. Tests of the strict Pigouvian hypothesis.

\begin{tabular}{|c|c|c|c|c|c|c|}
\hline & (1) & (2) & (3) & (4) & (5) & (6) \\
\hline VARIABLES & GHG_DIFF & GHG_DIFF & $\begin{array}{c}\text { GHG_DIFF } \\
(\text { GHG_DIFF <0) }\end{array}$ & $\begin{array}{c}\text { GHG_DIFF } \\
(\text { GHG_DIFF <0) }\end{array}$ & $\begin{array}{c}\text { GHG_DIFF } \\
(\text { GHG_DIFF }>0)\end{array}$ & $\begin{array}{c}\text { GHG_DIFF } \\
(\text { GHG_DIFF >0) }\end{array}$ \\
\hline GHG_DIFF & $\begin{array}{c}0.3877^{* * *} \\
(0.1118)\end{array}$ & $\begin{array}{c}0.2922^{* * *} \\
(0.0239)\end{array}$ & $\begin{array}{c}0.0055 \\
(0.2309)\end{array}$ & $\begin{array}{l}0.1002^{* *} \\
(0.0496)\end{array}$ & $\begin{array}{l}0.3046^{* *} \\
(0.1547)\end{array}$ & $\begin{array}{c}0.4779 * * * \\
(0.1011)\end{array}$ \\
\hline ET_REV & $\begin{array}{l}-0.0009 \\
(0.0108)\end{array}$ & & $\begin{array}{c}0.0074 \\
(0.0119)\end{array}$ & & $\begin{array}{l}-0.0067 \\
(0.0089)\end{array}$ & \\
\hline ET_RATE & $\begin{array}{c}0.0005^{* * *} \\
(0.0002)\end{array}$ & $\begin{array}{c}0.0006^{* * *} \\
(0.0001)\end{array}$ & $\begin{array}{c}0.0002 \\
(0.0003)\end{array}$ & $\begin{array}{c}0.0003^{* * *} \\
(0.0001)\end{array}$ & $\begin{array}{c}0.0004^{* * *} \\
(0.0001)\end{array}$ & $\begin{array}{c}0.0003^{* * *} \\
(0.0001)\end{array}$ \\
\hline G_GDP_PC & $\begin{array}{c}-0.0021^{* *} \\
(0.0008)\end{array}$ & $\begin{array}{c}-0.0026^{* * *} \\
(0.0002)\end{array}$ & $\begin{array}{l}-0.0002 \\
(0.0007)\end{array}$ & & $\begin{array}{c}-0.0027^{*} \\
(0.0014)\end{array}$ & $\begin{array}{c}-0.0051^{* * *} \\
(0.0010)\end{array}$ \\
\hline logGDP_PC & $\begin{array}{c}4.8135 \\
(4.3878)\end{array}$ & $\begin{array}{c}-0.6739^{* * *} \\
(0.0316)\end{array}$ & $\begin{array}{c}2.5782 \\
(5.8557)\end{array}$ & $\begin{array}{c}-0.6899 * * * \\
(0.0400)\end{array}$ & $\begin{array}{l}-1.0490 \\
(2.5792)\end{array}$ & $\begin{array}{c}-0.5485^{* * *} \\
(0.0973)\end{array}$ \\
\hline logGDP_PC2 & $\begin{array}{l}-0.2631 \\
(0.2148)\end{array}$ & & $\begin{array}{l}-0.1528 \\
(0.2771)\end{array}$ & & $\begin{array}{c}0.0147 \\
(0.1266)\end{array}$ & \\
\hline logENERGY_INT & $\begin{array}{c}-0.1570^{* *} \\
(0.0699)\end{array}$ & $\begin{array}{c}-0.2150^{* * *} \\
(0.0193)\end{array}$ & $\begin{array}{c}-0.3486^{* * *} \\
(0.0716)\end{array}$ & $\begin{array}{c}-0.3933^{* * *} \\
(0.0271)\end{array}$ & $\begin{array}{l}-0.1518 \\
(0.1094)\end{array}$ & $\begin{array}{c}-0.0946^{* *} \\
(0.0434)\end{array}$ \\
\hline VA_IND & $\begin{array}{c}0.0113^{* * *} \\
(0.0029)\end{array}$ & $\begin{array}{c}0.0124^{* * *} \\
(0.0013)\end{array}$ & $\begin{array}{c}0.0082^{* *} \\
(0.0035)\end{array}$ & $\begin{array}{c}0.0054^{* * *} \\
(0.0014)\end{array}$ & $\begin{array}{c}0.0054^{* * *} \\
(0.0018)\end{array}$ & $\begin{array}{c}0.0092^{* * * *} \\
(0.0016)\end{array}$ \\
\hline RLE & $\begin{array}{l}-0.0151 \\
(0.0288)\end{array}$ & $\begin{array}{c}0.0306^{* * *} \\
(0.0105)\end{array}$ & $\begin{array}{c}0.0433 \\
(0.0578)\end{array}$ & $\begin{array}{c}0.0155 \\
(0.0175)\end{array}$ & $\begin{array}{c}0.1017^{* * *} \\
(0.0377)\end{array}$ & $\begin{array}{l}0.0374^{* *} \\
(0.0167)\end{array}$ \\
\hline TREND & $\begin{array}{c}0.0072^{* * *} \\
(0.0013)\end{array}$ & $\begin{array}{c}0.0074^{* * *} \\
(0.0008)\end{array}$ & $\begin{array}{c}0.0025 \\
(0.0030)\end{array}$ & & $\begin{array}{c}0.0117^{* * *} \\
(0.0014)\end{array}$ & $\begin{array}{c}0.0092^{* * *} \\
(0.0011)\end{array}$ \\
\hline Constant & $\begin{array}{l}-21.0660 \\
(22.4496)\end{array}$ & $\begin{array}{c}7.7637^{* * * *} \\
(0.3915)\end{array}$ & $\begin{array}{c}-8.7689 \\
(31.1402)\end{array}$ & $\begin{array}{c}9.0987^{* * * *} \\
(0.4992)\end{array}$ & $\begin{array}{c}9.7913 \\
(13.4581)\end{array}$ & $\begin{array}{c}5.8300^{* * * *} \\
(1.2001)\end{array}$ \\
\hline Observations & 308 & 308 & 126 & 126 & 182 & 182 \\
\hline Number of id & 28 & 28 & 17 & 17 & 24 & 24 \\
\hline AR1 p value & 0.009 & 0.010 & 0.251 & 0.018 & 0.124 & 0.018 \\
\hline AR2 $p$ value & 0.277 & 0.229 & 0.254 & 0.546 & 0.131 & 0.067 \\
\hline Sargan test $p$ value & 1.00 & 1.00 & 1.00 & 1.00 & 1.00 & 1.00 \\
\hline
\end{tabular}

3-4) than of the overachieving ones (model 5-6). This pattern further corroborates the strict Pigouvian hypothesis. The size of the correction is rather large, since the estimated coefficient suggests that, if the countries in the sample increase their effective marginal tax pressure for ET by just 1 euro per ton equivalent, this will increase the relative distance from the target by 0.0006 (Model 2 in Table 3). As the average value of GHG_DIFF in the sample is 0.0694 (6,94\%), an increase of ET_RATE by 1 euro will increase GHG_DIFF by 7\%. In any event, the estimates show that, for both groups of countries, an increase of the ET_RATE increase GHG_DIFF, as the strict Pigouvian hypothesis predicts. Coming to the economic controls, as predicted by Ordás Criado, Valente, and Stengos (2011), we observe the scale effect for the whole sample, (variable G_GDP_PC) with a negative sign, which implies that faster growth brings about more emissions. Moreover, the 'defensive' effect (variable GDP_PC), is negative, implying that, in the long run, countries fail to revert to a steady state of more environmentally sustainable growth. No 
evidence is found, instead, of the environmental Kutznets curve effect, possibly because, in line with Harbaugh, Levinson, and Molloy Wilson (2006), the countries of the sample are fairly homogenous in terms of economic development. The estimates also confirm the expected negative sign on energy intensity in production. The positive value on TREND confirms its interpretation as a proxy for technological progress, which reduces air pollution, thus increasing the positive distance (or reducing the negative one) from the target. The latter effect seems stronger, since the coefficient on TREND is significant among the underachieving countries of Western Europe. Among the politico-institutional variables the positive sign on VA_IND confirms that more value added increases lobbying costs, which in turn increase GHG_DIFF. No significant difference seems to exist between the two subgroups of countries. The coefficient on the government efficiency at implementing policies is positive too and quite significant; once more this effect is concentrated in the Western European subsample. This suggests that there is less scope for Leviathan like behaviour in the pursuit of the environmental policy goals in the more established western democracies. The other politicoinstitutional variables usually turn out not statistically significant, because of their low within variance, while the between variance is captured by the fixed effects. Both the AR and the Sargan tests confirm the validity of the instruments.

\section{Testing the broad Pigouvian hypothesis}

The combination of a positive coefficient on ET_RATE and a lack of statistical significance on ET_REV is a necessary, but not sufficient evidence to conclude in support of the strict Pigouvian hypothesis. We cannot yet rule out the possibility that ET are used for other environmental concerns, not necessarily the reduction of GHG. If it were so, the results would be consistent also with the broad Pigouvian hypothesis, which posits that the complexity of environmental policy goals requires that all environmental policy instruments be directed to the attainment of environmental goals. In other words, the support for the strict Pigouvian hypothesis cannot exclude the broad Pigouvian interpretation because the restricted nature of the dependent variable used (GHG_DIFF), too limited to represent the whole environmental policy of the country. To overcome this problem, Equation (2) features the countries' expenditures for environmental protection in percentage of GDP as the dependent variable (ENV_PROT). Environmental protection expenditures are the most comprehensive aggregate of government outlays for environmental purposes for which Eurostat collects information. Moreover, since the broad Pigouvian hypothesis posits that environmental tax revenues must be spent for environmental concerns, we concentrate the analysis on ET_REV and check whether they remain not statistically significant. Table 4 illustrates the results.

All models of Table 4 show a negative correlation between ET revenues and environmental protection expenditures, albeit not a statistically significant one. This is evidence against the broad Pigouvian hypothesis, which predicts a positive and significant sign. The dynamic structure of the estimating procedure ensures that this result does not depend on the time difference between the moments when revenues are collected and when they are spent. Higher debt levels seem instead to be correlated with environmental protection expenditures. The income-related variables reveal that faster economic growth is associated with greater expenditures for environmental protection in Western European countries; the opposite seems true for the Eastern ones, possibly because the production technologies in that subsample are more environmentally friendly. All the other variables basically keep the same signs and significance levels of the estimates of Equation (1). Once more, the AR and the Sargan tests confirm the validity of the instruments.

\section{Testing the double dividend hypothesis}

The double dividend hypothesis refers to a substitution of ET for other taxes characterized by larger and more distortive excess burdens. As the excess burden of taxation increases with the square of the marginal tax rate, earlier contributions to this literature concur in pointing out the personal income taxes as the natural candidate for substitution (OECD 2011; Schöb 2003; Parry 1998; Goulder 1995). This hypothesis gained some prominence in the European policy debate at the turn of the 
Table 4. Tests of the broad Pigouvian hypothesis.

\begin{tabular}{|c|c|c|c|c|c|c|}
\hline & (1) & (2) & (3) & (4) & (5) & (6) \\
\hline VARIABLES & ENV_EXP & ENV_EXP & $\begin{array}{c}\text { ENV_EXP } \\
(\text { GHG_DIFF < } 0)\end{array}$ & $\begin{array}{c}\text { ENV_EXP } \\
(\text { GHG_DIFF < } 0)\end{array}$ & $\begin{array}{c}\text { ENV_EXP } \\
(\text { GHG_DIFF }>0)\end{array}$ & $\begin{array}{c}\text { ENV_EXP } \\
\left(G H G \_D I F F>0\right)\end{array}$ \\
\hline ENV_EXP $\mathrm{E}_{\mathrm{t}-1}$ & $\begin{array}{c}0.4509^{* * * *} \\
(0.0163)\end{array}$ & $\begin{array}{l}0.1863^{* * *} \\
(0.0932)\end{array}$ & $\begin{array}{c}0.0633 \\
(0.0784)\end{array}$ & $\begin{array}{l}-0.0366 \\
(0.2052)\end{array}$ & $\begin{array}{c}0.1992^{* * * *} \\
(0.0486)\end{array}$ & $\begin{array}{l}-0.0944 \\
(0.1434)\end{array}$ \\
\hline ET_REV & $\begin{array}{l}-0.0093 \\
(0.0090)\end{array}$ & & $\begin{array}{c}0.0065 \\
(0.0135)\end{array}$ & & $\begin{array}{l}-0.0079 \\
(0.0112)\end{array}$ & \\
\hline DEBT & & $\begin{array}{l}0.0047^{* *} \\
(0.0019)\end{array}$ & & $\begin{array}{c}0.0015 \\
(0.0020)\end{array}$ & & $\begin{array}{c}0.0035 \\
(0.0035)\end{array}$ \\
\hline OTHER_REV & & $\begin{array}{l}-0.0093 \\
(0.0097)\end{array}$ & & $\begin{array}{l}-0.0129 \\
(0.0187)\end{array}$ & & $\begin{array}{c}0.0018 \\
(0.0176)\end{array}$ \\
\hline G_GDP_PC & $\begin{array}{c}-0.0035^{* * *} \\
(0.0010)\end{array}$ & $\begin{array}{c}-0.0033^{* *} \\
(0.0014)\end{array}$ & $\begin{array}{c}-0.0084^{* * * *} \\
(0.0021)\end{array}$ & $\begin{array}{c}-0.0068^{*} \\
(0.0038)\end{array}$ & $\begin{array}{l}0.0031^{* *} \\
(0.0015)\end{array}$ & $\begin{array}{c}0.0022 \\
(0.0033)\end{array}$ \\
\hline logGDP_PC & $\begin{array}{c}-0.6111^{* * *} \\
(0.0899)\end{array}$ & $\begin{array}{l}-0.1901 \\
(0.3042)\end{array}$ & $\begin{array}{l}-0.0962 \\
(0.3128)\end{array}$ & $\begin{array}{l}-0.4031 \\
(0.6319)\end{array}$ & $\begin{array}{c}-0.8832^{* * *} \\
(0.3097)\end{array}$ & $\begin{array}{l}-0.3679 \\
(0.6925)\end{array}$ \\
\hline logENERGY_INT & $\begin{array}{c}-0.4074^{* * *} \\
(0.1256)\end{array}$ & $\begin{array}{c}-0.3401^{*} \\
(0.1927)\end{array}$ & $\begin{array}{l}-0.0598 \\
(0.2416)\end{array}$ & $\begin{array}{c}0.3267 \\
(0.2106)\end{array}$ & $\begin{array}{c}-0.4893^{*} \\
(0.2962)\end{array}$ & $\begin{array}{c}-1.0789^{* * *} \\
(0.4173)\end{array}$ \\
\hline VA_IND & $\begin{array}{c}0.0087^{* * *} \\
(0.0028)\end{array}$ & $\begin{array}{c}0.0113 \\
(0.0077)\end{array}$ & $\begin{array}{l}-0.0042 \\
(0.0043)\end{array}$ & $\begin{array}{c}0.0167 \\
(0.0211)\end{array}$ & $\begin{array}{c}-0.0106^{* *} \\
(0.0043)\end{array}$ & $\begin{array}{l}-0.0232 \\
(0.0310)\end{array}$ \\
\hline RLE & $\begin{array}{l}0.1297^{* *} \\
(0.0543)\end{array}$ & $\begin{array}{c}0.0699 \\
(0.1346)\end{array}$ & $\begin{array}{c}0.1702 \\
(0.1726)\end{array}$ & $\begin{array}{c}0.4312^{* * * *} \\
(0.0549)\end{array}$ & $\begin{array}{c}0.1666 \\
(0.2108)\end{array}$ & $\begin{array}{l}-0.2707 \\
(0.3088)\end{array}$ \\
\hline TREND & $\begin{array}{c}-0.0109^{* *} \\
(0.0049)\end{array}$ & $\begin{array}{c}-0.0191^{*} \\
(0.0106)\end{array}$ & $\begin{array}{l}-0.0055 \\
(0.0091)\end{array}$ & $\begin{array}{c}0.0030 \\
(0.0124)\end{array}$ & $\begin{array}{l}-0.0187 \\
(0.0114)\end{array}$ & $\begin{array}{c}-0.0486^{*} \\
(0.0253)\end{array}$ \\
\hline Constant & $\begin{array}{c}8.5480^{* * * *} \\
(1.1164)\end{array}$ & $\begin{array}{c}4.0867 \\
(3.3709)\end{array}$ & $\begin{array}{c}1.7334 \\
(4.0891)\end{array}$ & $\begin{array}{c}2.6316 \\
(6.2261)\end{array}$ & $\begin{array}{c}12.3803^{* * *} \\
(3.2608)\end{array}$ & $\begin{array}{l}10.8437^{*} \\
(5.9042)\end{array}$ \\
\hline Observations & 308 & 308 & 126 & 126 & 182 & 182 \\
\hline Number of id & 28 & 28 & 17 & 17 & 24 & 24 \\
\hline AR1 $p$ value & 0.005 & 0.11 & 0.43 & 0.83 & 0.04 & 0.045 \\
\hline AR2 $p$ value & 0.27 & 0.19 & 0.29 & 0.24 & 0.46 & 0.32 \\
\hline $\begin{array}{l}\text { Sargan test } \\
\text { p value }\end{array}$ & 1.00 & 1.00 & 1.00 & 1.00 & 1.00 & 1.00 \\
\hline
\end{tabular}

Arellano-Bond dynamic panel-data estimation, in (2) (4) and (6) the variable DEBT is assumed to be endogenous. Standard errors in parentheses. ${ }^{* * *} p<0.01,{ }^{* *}$ $\mathrm{p}<0.05,{ }^{*} \mathrm{p}<0.1$

century, when the Red-Green coalition government in Germany placed it with great emphasis in its political platform. Indeed, such debate occurred during the sample period of our analysis.

In the estimates of Equation (3) the covariate of interest is MARTAX, the proxy for effective marginal tax pressure in personal income taxation. We consider MARTAX as endogenous in the estimation. A negative sign on MARTAX reveals an attempt to lower high-excess burden taxes with environmental ones, i.e., a proper attempt to attain a double dividend.

The estimates show that, when we consider ET_REV, the negative and highly significant coefficient on MARTAX is evidence of exchange of ET with other taxes with the personal income tax, especially among the countries that have already attained their target (model 3). In particular, the value of the coefficient reveals that a reduction by 1 percentage point of marginal tax pressure on personal income implies a 0.0471 percentage point increase of ET_REV, a nonnegligible value (model 1 in Table 5). Countries apparently have still a fairly large leeway in pursuing a double dividend type of fiscal strategy. This result contrasts with the implications of the mostly theoretical or simulated models that cast doubts on the possibility to achieve a double dividend because of large tax interaction effects (Bovenberg and De Mooij

Table 5. Tests of the 'double dividend' hypothesis.

\begin{tabular}{|c|c|c|c|}
\hline & (1) & (2) & (3) \\
\hline VARIABLES & ET_REV & $\begin{array}{c}\text { ET_REV (GHG_DIFF } \\
<0)\end{array}$ & $\begin{array}{c}\text { ET_REV (GHG_DIFF } \\
>0)\end{array}$ \\
\hline ET_REV $\mathrm{t}_{\mathrm{t}-1}$ & $\begin{array}{c}0.5914^{* * *} \\
(0.1115)\end{array}$ & $\begin{array}{l}0.2984^{*} \\
(0.1540)\end{array}$ & $\begin{array}{c}0.6760^{* * * *} \\
(0.1369)\end{array}$ \\
\hline MAR_TAX & $\begin{array}{c}-0.0471^{* * *} \\
(0.0166)\end{array}$ & $\begin{array}{l}-0.0349 \\
(0.0258)\end{array}$ & $\begin{array}{c}-0.0232^{* *} \\
(0.0106)\end{array}$ \\
\hline DEBT & $\begin{array}{c}0.0122^{* * *} \\
(0.0018)\end{array}$ & $\begin{array}{c}0.0110^{* * *} \\
(0.0030)\end{array}$ & $\begin{array}{c}0.0159^{* * * *} \\
(0.0043)\end{array}$ \\
\hline G_GDP_PC & $\begin{array}{c}-0.0185^{* * *} \\
(0.0070)\end{array}$ & $\begin{array}{l}-0.0064 \\
(0.0063)\end{array}$ & $\begin{array}{c}-0.0221^{* *} \\
(0.0109)\end{array}$ \\
\hline RLE & $\begin{array}{l}-0.3667 \\
(0.2808)\end{array}$ & $\begin{array}{c}-0.8202^{* * *} \\
(0.3157)\end{array}$ & $\begin{array}{l}-0.1478 \\
(0.7277)\end{array}$ \\
\hline TREND & $\begin{array}{c}-0.0191^{* *} \\
(0.0097)\end{array}$ & $\begin{array}{c}-0.0596^{* * *} \\
(0.0109)\end{array}$ & $\begin{array}{l}-0.0234 \\
(0.0159)\end{array}$ \\
\hline Constant & $\begin{array}{c}4.5203^{* * *} \\
(1.2141)\end{array}$ & $\begin{array}{c}7.1832^{* * *} \\
(2.5996)\end{array}$ & $\begin{array}{c}2.3734 \\
(1.5919)\end{array}$ \\
\hline Observations & 253 & 112 & 141 \\
\hline Number of id & 23 & 15 & 19 \\
\hline AR1 p value & 0.006 & 0.03 & 0.010 \\
\hline AR2 $p$ value & 0.99 & 0.52 & 0.40 \\
\hline $\begin{array}{l}\text { Sargan test } \\
\text { p value }\end{array}$ & 1.00 & 1.00 & 1.00 \\
\hline
\end{tabular}

Arellano-Bond dynamic panel-data estimation, variable MARTAX is assumed to be endogenous.

Standard errors in parentheses. ${ }^{* *} p<0.01,{ }^{* *} p<0.05,{ }^{*} p<0.1$ 
Table 6. Tests of the Leviathan hypothesis. Dependent variable: General Services Expenditures (GS_EXP).

\begin{tabular}{|c|c|c|c|c|c|c|}
\hline & (1) & (2) & (3) & (4) & (5) & (6) \\
\hline VARIABLES & GS_EXP & GS_EXP & $\begin{array}{c}\text { GS_EXP } \\
(\text { GHG_DIFF < }<)\end{array}$ & $\begin{array}{c}\text { GS_EXP } \\
(\text { GHG_DIFF < }<)\end{array}$ & $\begin{array}{c}\text { GS_EXP } \\
\left(G H G \_D I F F>0\right)\end{array}$ & $\begin{array}{c}\text { GS_EXP } \\
\left(G H G \_D I F F>0\right)\end{array}$ \\
\hline GS_EXP & $\begin{array}{c}0.5947^{* * *} \\
(0.0350)\end{array}$ & $\begin{array}{c}0.4836^{* * *} \\
(0.0400)\end{array}$ & $\begin{array}{c}0.4829^{* * * *} \\
(0.0651)\end{array}$ & $\begin{array}{l}0.1534^{* *} \\
(0.0632)\end{array}$ & $\begin{array}{c}0.3911^{* * *} \\
(0.0545)\end{array}$ & $\begin{array}{c}0.2869^{* * *} \\
(0.0528)\end{array}$ \\
\hline ET_REV & $\begin{array}{c}0.0063 \\
(0.0262)\end{array}$ & & $\begin{array}{l}-0.0028 \\
(0.0786)\end{array}$ & & $\begin{array}{l}-0.0362 \\
(0.0418)\end{array}$ & \\
\hline DEBT & & $\begin{array}{c}0.0295 * * * \\
(0.0027)\end{array}$ & & $\begin{array}{c}0.0352^{* * *} \\
(0.0069)\end{array}$ & & $\begin{array}{c}0.0282^{* * *} \\
(0.0074)\end{array}$ \\
\hline OTHER_REV & & $\begin{array}{l}-0.0115 \\
(0.0197)\end{array}$ & & $\begin{array}{c}0.0028 \\
(0.0146)\end{array}$ & & $\begin{array}{l}-0.0096 \\
(0.0617)\end{array}$ \\
\hline G_GDP_PC & $\begin{array}{c}-0.0416^{* * *} \\
(0.0047)\end{array}$ & $\begin{array}{c}-0.0416^{* * *} \\
(0.0040)\end{array}$ & $\begin{array}{c}-0.0126^{*} \\
(0.0065)\end{array}$ & $\begin{array}{c}-0.0183^{* * *} \\
(0.0069)\end{array}$ & $\begin{array}{c}-0.0421^{* * *} \\
(0.0039)\end{array}$ & $\begin{array}{c}-0.0441^{* * *} \\
(0.0054)\end{array}$ \\
\hline logGDP_PC & $\begin{array}{c}-1.4331^{* *} \\
(0.5762)\end{array}$ & $\begin{array}{c}1.4698^{* * *} \\
(0.5479)\end{array}$ & $\begin{array}{c}-4.0198^{* * *} \\
(0.6408)\end{array}$ & $\begin{array}{c}0.1890 \\
(1.5217)\end{array}$ & $\begin{array}{c}-1.6884^{* *} \\
(0.7558)\end{array}$ & $\begin{array}{c}3.3112^{* * *} \\
(1.0954)\end{array}$ \\
\hline RLE & $\begin{array}{c}0.8829 * * \\
(0.3916)\end{array}$ & $\begin{array}{l}0.5951^{*} \\
(0.3436)\end{array}$ & $\begin{array}{c}0.1937 \\
(0.2394)\end{array}$ & $\begin{array}{l}0.7731^{*} \\
(0.4244)\end{array}$ & $\begin{array}{c}1.0560 \\
(0.8051)\end{array}$ & $\begin{array}{c}0.2979 \\
(0.4514)\end{array}$ \\
\hline TREND & $\begin{array}{c}-0.0182^{* * *} \\
(0.0066)\end{array}$ & $\begin{array}{c}-0.1162^{* * *} \\
(0.0097)\end{array}$ & $\begin{array}{c}0.0115 \\
(0.0092)\end{array}$ & $\begin{array}{c}-0.0932^{* * *} \\
(0.0268)\end{array}$ & $\begin{array}{c}-0.0362^{* *} \\
(0.0169)\end{array}$ & $\begin{array}{c}-0.1851^{* * *} \\
(0.0349)\end{array}$ \\
\hline Constant & $\begin{array}{c}16.6080^{* * *} \\
(6.2076)\end{array}$ & $\begin{array}{c}-13.3461^{* *} \\
(6.1947)\end{array}$ & $\begin{array}{c}45.5019 * * * \\
(7.1775)\end{array}$ & $\begin{array}{c}0.6400 \\
(16.8728)\end{array}$ & $\begin{array}{c}20.7684^{* * *} \\
(7.7455)\end{array}$ & $\begin{array}{c}-29.5037^{* * *} \\
(11.2213)\end{array}$ \\
\hline Observations & 308 & 308 & 126 & 126 & 182 & 182 \\
\hline Number of id & 28 & 28 & 17 & 17 & 24 & 24 \\
\hline AR1 p value & 0.057 & 0.056 & 0.081 & 0.09 & 0.09 & 0.10 \\
\hline AR2 $p$ value & 0.427 & 0.432 & 0.55 & 0.185 & 0.39 & 0.39 \\
\hline Sargan test $p$ value & 1.00 & 1.00 & 1.00 & 1.00 & 1.00 & 1.00 \\
\hline
\end{tabular}

1994). Rather the welfare gains associated with previous distortionary effects of taxation appear to be significant (Parry 1998), at least in the sample under study. Countries that must still reduce GHG emissions seem more prone to substitute ET (model 4). These results are obtained controlling for the countries revenue requirements, proxied by the variable DEBT, which has the expected positive and significant coefficient. This result holds on all model specifications and samples. All the other variables maintain their signs and levels of significance; the diagnostics ensures the validity of the instruments.

\section{Direct tests of the Leviathan hypothesis}

So far, the evidence is mostly in favour of the strict Pigouvian hypothesis; this rules out the possibility to accept the Leviathan hypothesis a contrario, i.e., as the opposite view to hypotheses that are not supported by the data. In this context, it is important to directly test the hypothesis that governments behave like Leviathans in environmental policy; if such hypothesis is rejected the results in favour of the strict Pigouvian hypothesis would be further corroborated. To perform this robustness check we have estimated Equation (4) for general services expenditures
(GS_EXP) and social protection expenditures (SC_EXP), two quite opposite types of expenditure items: the first is closest to the definition of public goods, while the second is the most redistributive expenditure category within the Eurostat classification. Table 6 reports the results of the estimates of Equation (4) for these two dependent variables.

As for GS_EXP, the estimated coefficients are never statistically significant (Table 6). Nor does ET_REV ever appear to be statistically significantly correlated with SC_EXP, those in favour of which a government that is not electorally accountable should spend the ET revenues, especially in view of their low political cost (Table 7). The results in Table 7 should be interpreted with caution, however, as the AR2 tests fail to validate the instruments in models (1), (2) and (3). In all models where the instruments are valid, the coefficient on ET_REV is not statistically significant. The estimates of Equation (4), disaggregated for the two subsamples of overachieving and underachieving countries, are not qualitatively different from these of the whole sample. The other variables show the expected signs. All in all, there is no evidence that ET are employed to secure power bases or for vote buying purposes; this further supports the results in favour of the strict Pigouvian hypothesis. 
Table 7. Tests of the Leviathan hypothesis. Dependent variable: Social Protection Expenditures (SC_EXP).

\begin{tabular}{|c|c|c|c|c|c|c|}
\hline \multirow[b]{2}{*}{ VARIABLES } & (1) & (2) & (3) & (4) & (5) & (6) \\
\hline & SC_EXP & SC_EXP & $\begin{array}{c}\text { SC_EXP } \\
\left(G H G \_D I F F<0\right)\end{array}$ & $\begin{array}{c}\text { SC_EXP } \\
(\text { GHG_DIFF }<0)\end{array}$ & $\begin{array}{c}\text { SC_EXP } \\
\left(G H G \_D I F F>0\right)\end{array}$ & $\begin{array}{c}\text { SC_EXP } \\
(\text { GHG_DIFF >0) }\end{array}$ \\
\hline$S C_{-} E_{X P}$ & $0.5679 * * *$ & $0.5876^{* * *}$ & $0.6784^{* * *}$ & $0.4275^{*}$ & $0.5897^{* * *}$ & $0.6331^{* * *}$ \\
\hline & $(0.0511)$ & $(0.0571)$ & $(0.0726)$ & $(0.2446)$ & $(0.0451)$ & $(0.0967)$ \\
\hline ET_REV & $\begin{array}{c}0.0686 \\
(0.0462)\end{array}$ & & $\begin{array}{c}0.0487 \\
(0.1563)\end{array}$ & & $\begin{array}{l}-0.0430 \\
(0.0546)\end{array}$ & \\
\hline DEBT & & $\begin{array}{l}-0.0010 \\
(0.0059)\end{array}$ & & $\begin{array}{c}-0.0207^{* * *} \\
(0.0067)\end{array}$ & & $\begin{array}{l}-0.0066 \\
(0.0102)\end{array}$ \\
\hline OTHER_REV & & $\begin{array}{l}-0.0319 \\
(0.0443)\end{array}$ & & $\begin{array}{c}-0.1306^{* * *} \\
(0.0390)\end{array}$ & & $\begin{array}{c}0.0240 \\
(0.0651)\end{array}$ \\
\hline G_GDP_PC & $\begin{array}{c}-0.1630^{* * *} \\
(0.0099)\end{array}$ & $\begin{array}{c}-0.1620 * * * \\
(0.0086)\end{array}$ & $\begin{array}{c}-0.1850^{* * *} \\
(0.0181)\end{array}$ & $\begin{array}{l}-0.1002 \\
(0.0659)\end{array}$ & $\begin{array}{c}-0.1551^{* * *} \\
(0.0041)\end{array}$ & $\begin{array}{c}-0.1620^{* * *} \\
(0.0083)\end{array}$ \\
\hline logGDP_PC & $\begin{array}{c}-4.9498^{* * *} \\
(1.7341)\end{array}$ & $\begin{array}{c}-4.0651^{* * *} \\
(1.3835)\end{array}$ & $\begin{array}{c}-4.6653^{*} \\
(2.7882)\end{array}$ & $\begin{array}{c}-16.6238^{* *} \\
(6.7352)\end{array}$ & $\begin{array}{c}-1.9339^{* * * *} \\
(0.6562)\end{array}$ & $\begin{array}{c}-2.2887^{* * *} \\
(0.7726)\end{array}$ \\
\hline RLE & $\begin{array}{l}0.3937^{* *} \\
(0.1884)\end{array}$ & $\begin{array}{l}0.7925^{*} \\
(0.4471)\end{array}$ & $\begin{array}{c}0.2370 \\
(0.3074)\end{array}$ & $\begin{array}{c}0.7834 \\
(0.5506)\end{array}$ & $\begin{array}{l}0.6643^{*} \\
(0.3732)\end{array}$ & $\begin{array}{c}0.5068 \\
(0.3775)\end{array}$ \\
\hline TREND & $\begin{array}{c}0.0765^{* * * *} \\
(0.0220)\end{array}$ & $\begin{array}{c}0.0677^{* *} \\
(0.0294)\end{array}$ & $\begin{array}{l}0.0887^{* *} \\
(0.0348)\end{array}$ & $\begin{array}{c}0.2668^{* * *} \\
(0.1013)\end{array}$ & $\begin{array}{c}0.0341^{* * *} \\
(0.0098)\end{array}$ & $\begin{array}{c}0.0382 \\
(0.0326)\end{array}$ \\
\hline Constant & $\begin{array}{c}57.3412^{* * *} \\
(18.5761)\end{array}$ & $\begin{array}{c}48.8972^{* * * *} \\
(16.0374)\end{array}$ & $\begin{array}{l}54.4994^{*} \\
(31.5573)\end{array}$ & $\begin{array}{c}190.5833^{* *} \\
(76.3091)\end{array}$ & $\begin{array}{c}25.9914^{* * * *} \\
(6.8856)\end{array}$ & $\begin{array}{c}28.3897^{* * * *} \\
(8.5245)\end{array}$ \\
\hline Observations & 308 & 308 & 126 & 126 & 182 & 182 \\
\hline Number of id & 28 & 28 & 17 & 17 & 24 & 24 \\
\hline AR1 $p$ value & 0.0057 & 0.003 & 0.10 & 0.94 & 0.00 & 0.01 \\
\hline AR2 $p$ value & 0.015 & 0.012 & 0.03 & 0.44 & 0.43 & 0.33 \\
\hline Sargan test $p$ value & 1.00 & 1.00 & 1.00 & 1.00 & 1.00 & 1.00 \\
\hline
\end{tabular}

Arellano-Bond dynamic panel-data estimation, in (2) (4) and (6) variable DEBT is assumed to be endogenous. Standard errors in parentheses. ${ }^{* * *} \mathrm{p}<0.01,{ }^{* *}$ $p<0.05, * p<0.1$

\section{Conclusions}

In the sample under examination, the empirical analysis of this paper lends support to the interpretation that European governments use ET in a Pigouvian way. The positive correlation between ET rates and relative distance from the target, together with the lack of statistical significance on measures of environmental tax revenues, suggests that high Pigouvian tax rates reduce the environmental externality represented by GHG emissions and therefore shrink the tax base for these taxes, disincentivizing behaviours that generate GHG. Both the countries that have already attained their GHG emissions targets and those that still have to meet it are characterized by similar levels of correlation between ET rates and reduction of GHG emissions; this suggests that environmental policies tend to become embedded in the fiscal system even after certain policy goals are reached.

The analysis also finds some evidence that governments resort to ET to achieve the double dividend of reducing the GHG emissions and the distorting effects of progressivity in personal income taxation. Although the evidence in favour of this motivation appears quantitatively less important than for the strict Pigouvian hypothesis, it is sufficiently compelling to identify the resort of ET to reduce excess burdens associated with personal income taxation. Finally, the evidence in favour of Leviathan style behaviours is quite inconsistent.

The results of our analysis can be quite helpful for the same group of counties that, in compliance with the COP21 agreement, in May 2018 have committed themselves to further decrease their GHG emissions by $30 \%$ before the year 2030 (EU regulation 2018/ 842). In quantitative terms this effort is three times larger and to be achieved in a slightly shorter time frame than the one which we have investigated in this paper. Regulation 2018/42 once more sets a collective target for the EU and a set of individual efforts of the member countries, which in some cases can go well beyond the $-30 \%$ target and are again by and large separated along the East-West Europe divide. It is hence clear that, for such an ambitious policy goal to be attained, the instruments must be appropriate. The policy implication deriving from this paper points out that countries should rely on Pigouvian taxes more, especially those that have to attain the most demanding reductions. Countries that are near the peak of their rate-revenues relationship can 'recycle' personal 
income taxes with ET, to achieve the environmental goal and an overall improvement of the efficiency of the economy.

\section{Disclosure statement}

No potential conflict of interest was reported by the authors.

\section{ORCID}

Isabelle Cadoret (D) http://orcid.org/0000-0002-3083-3703

\section{References}

Acemoglu, D., P. Aghion, L. Bursztyn, and D. Hemous. 2012. "The Environment and Directed Technical Change." American Economic Review 102 (1): 131-166. doi:10.1257/ aer.102.1.131.

Aidt, T. S. 1998. "Political Internalization of Economic Externalities and Environmental Policy." Journal of Public Economics 69: 1-16.

Aidt, T. S. 2010. "Green Taxes: Refunding Rules and Lobbying." Journal of Environmental Economics and Management 60 (1): 2010. doi:10.1016/j.jeem.2010. 04.001.

Arrow, K., B. Bolin, R. Costanza, P. Dasgupta, C. Folke, C. S. Holling, B. O. Jansson, K. G. Maler, and D. Pimentel. 1995. "Economic Growth, Carrying Capacity, and the Environment." Ecological Economics 15 (2): 91-95. doi:10.1016/0921-8009(95)00059-3.

Baumol, W. J., and W. E. Oates. 1988. The Theory of Environmental Policies. Cambridge: Cambridge University Press.

Benjamin, C., I. Cadoret, and M. H. Hubert. 2015. "The European Climate Policy Is Ambitious: Myth or Reality?.” Revue D'économie Politique 125 (5): 731-753. doi: 10.3917/ redp.255.0731.

Bento, A. M., and M. Jacobsen. 2007. "Ricardian Rents, Environmental Policy and the 'Double-dividend' Hypothesis." Journal of Environmental Economics and Management 53 (1): 17-31. doi:10.1016/j.jeem.2006.03.006.

Bosquet, B. 2000. "Environmental Tax Reform: Does It Work? A Survey of the Empirical Evidence." Ecological Economics 34 (1): 19-32. doi:10.1016/S0921-8009(00)00173-7.

Botta, E., and T. Kozluk. 2014. Measuring Environmental Policy Stringency in Oecd Countries: a Composite Index Approach." OECD Economics Department Working Papers. doi: 10.1787/5jxrjnc45gvg-en

Bovenberg, A. L., and L. H. Goulder. 2002. "Environmental Taxation." In Handbook of Public Economics, edited by A. Auerbach and M. Feldstein, 1471-1547. New York: North Holland.
Bovenberg, A. L., L. H. Goulder, and M. R. Jacobsen. 2008. "Cost of Alternative Environmental Policy Instruments in the Presence of Industry Compensation Requirements." Journal of Public Economics 92 (5-6): 1236-1253. doi:10.1016/j.jpubeco.2007.09.013.

Bovenberg, L., and R. De Mooij. 1994. "Environmental Levies and Distortionary Taxation." American Economic Review 84: 1085-1089.

Brock, W. A., and M. S. Taylor. 2010. "The Green Solow Model." Journal of Economic Growth 15 (2): 127-153. doi:10.1007/s10887-010-9051-0.

Cadoret, I., and F. Padovano, 2019. "Exploring the Determinants and Consequences of the Stringency of Environmental Policies." Center Condorcet Working Papers. 2019/6ccr

Conconi, P. 2003. "Green Lobbies and Transboundary Pollution in Large Open Economies." Journal of International Economics 59 (2): 399-422. doi:10.1016/ S0022-1996(02)00023-5.

Congleton, R. 1992. "Political Institutions and Pollution Control." The Review of Economics and Statistics 74 (3): 412-421. doi:10.2307/2109485.

Congleton, R. 2002. "Agency Problems and The Allocation Of International Environmental Grants: The Return to Rio." Journal Of Public Finance and Public Choice 20 (2-3): 125146. doi:.

Cremer, H., F. Gahvari, and N. Ladoux. 1998. "Externalities and Optimal Taxation." Journal of Public Economics 70 (3): 343-364. doi:10.1016/S0047-2727(98)00039-5.

Decision n. 2009. "406/2009 of the EU Parliament and of the Council of Ministries." Journal Officiel De l'Union Europeenne 140: 136-148.

Duit, A., P. H. Feindt, and J. Meadowcroft. 2016. "Greening Leviathan: The Rise of the Environmental State?" Environmental Politics 25 (1): 1-23. doi:10.1080/ 09644016.2015.1085218.

European Commission. 2011. Sustainable Development in the European Union and Monitoring Report of the EU Sustainable Development Strategy.

European Commission. 2014. Special Eurobarometer 416. Attitudes of European Citizens Towards the Environment. Bruxelles: European Union.

Fouquet, D., and T. Johanson. 2008. "European Renewable Energy Policy at Crossroads - Focus on Electricity Support Mechanisms." Energy Policy 36: 4079-4092. doi:10.1016/j. enpol.2008.06.023.

Fredriksson, P. 1997. “The Political Economy of Pollution Taxes in a Small Open Economy." Journal of Environmental Economics and Management 33: 44-58. doi:10.1006/jeem.1996.0979.

Fredriksson, P., H. Vollebergh, and E. Dijkgraaf. 2004. "Corruption and Energy Efficiency in Oecd Countries: Theory and Evidence." Journal Of Environmental Economics and Management 47 (2): 207-231. doi: 10.1016/ j.jeem.2003.08.001. 
Fredriksson, P., and J. Svensson. 2003. "Political Instability, Corruption and Policy Formation: The Case of Environmental Policy." Journal of Public Economics 87: 1383-1405. doi:10.1016/S0047-2727(02)00036-1.

Fredriksson, P., and T. Sterner. 2005. "The Political Economy of Refunded Emissions Payment Programs." Economic Letters 87: 113-119. doi:10.1016/j.econlet.2004.11.001.

Gersbach, H., and T. Requate. 2004. "Emission Taxes and Optimal Refunding Schemes." Journal of Public Economics 88: 713-725. doi:10.1016/S0047-2727(02)00215-3.

Goulder, L. H. 1995. "Environmental Taxation and the 'Double Dividend': A Reader's Guide." International Tax Public Finance 2: 57-198. doi:10.1007/BF00877495.

Harbaugh, W. T., A. Levinson, and D. Molloy Wilson. 2006. "Reexamining the Empirical Evidence for an Environmental Kuznets Curve." Review of Economics and Statistics 84: 541-551. doi:10.1162/003465302320259538.

Hoerner, A. J., and B. Bosquet 2001. "Environmental Tax Reform: The European Experience." Center for a Sustainable Economy, Washington DC, February.

Jacobs, B., and R. A. de Mooij. 2015. "Pigou Meets Mirrlees: On the Irrelevance of Tax Distortions for the Second-best Pigouvian Tax." Journal of Environmental Economics and Management 71: 90-108. doi:10.1016/j.jeem.2015.01.003.

Kirchgassner, G., and F. Schneider. 2003. "On the Political Economy of Environmental Policy." Public Choice 115: 369-396. doi:10.1023/A:1024289627887.

Kosonen, K., and G. Nicodème 2009. The role of fiscal instruments in environmental policy, DG TAXUD Working Paper No. 19 2009,

Lai, Y.-B. 2009. "Is a Double Dividend Better than a Single Dividend?" Journal of Institutional and Theoretical Economics 165: 342-363. doi:10.1628/093245609789273286.

Morse, S. 2006. "Is Corruption Bad for Environmental Sustainability? A Cross-National Analysis." Ecology and Society 11: 1-22. doi:10.5751/ES-01656-110122.

Oates, W. E., and P. R. Portney. 2003. "The Political Economy of Environmental Policy.” In Handbook of Environmental
Economics, edited by K. G. Maler and J. R. Vincent, 325-354. Elsevier, Amsterdam: Elsevier.

OECD. 2011. Environmental Taxation A Guide for Policy Makers. Paris: OECD.

Ordás Criado, C., S. Valente, and T. Stengos. 2011. "Growth and Pollution Convergence: Theory and Evidence." Journal of Environmental Economics and Management 62: 199-214. doi:10.1016/j.jeem.2010.10.009.

Parry, I. W. H. 1998. "The Double Dividend: When You Get It and When You Don't." In Proceedings Annual Conference on Taxation and Minutes of the Annual Meeting of the National Tax Association. Philadelphia, PA.

Pearce, D., and C. Palmer. 2001. "Public and Private Spending for Environmental Protection: A Cross-Country Policy Analysis." Fiscal Studies 22: 403-456. doi:10.1111/j.14755890.2001.tb00048.x.

Polk, A., and A. Schmutzler. 2005. "Lobbying against Environmental Regulation V. Lobbying for Loopholes." European Journal of Political Economy 21: 915-931. doi:10.1016/j.ejpoleco.2005.04.003.

Sandmo, A. 2000. The Public Economics of the Environment. Oxford: Oxford University Press.

Sandmo, A. 2010. "The Scale and Scope of Environmental Taxation.” NHH Dept. of Economics Discussion Paper n. $18 / 2009$.

Schöb, R., 2003. "The Double Dividend Hypothesis of Environmental Taxation. A Survey." Cesifo working papers series n. 946.

Sterner, T., and L. H. Isaksson. 2006. "Refunded Emission Payments Theory, Distribution of Costs, and Swedish Experience of NOx Abatement." Ecological Economics 57: 93-106. doi:10.1016/j.ecolecon.2005. 03.008.

Thalmann, P. 2004. "The Public Acceptance of Green Taxes: 2 Million Voters Express Their Opinion." Public Choice 119: 179-217. doi:10.1023/B: PUCH.0000024165.18082.db. 


\section{Appendix. Additional tests and estimates}

Table A1. Levin-Lin-Chu unit-root test.

\begin{tabular}{|c|c|c|c|c|}
\hline \multirow[b]{2}{*}{ VARIABLES } & \multicolumn{2}{|c|}{ Without Trend } & \multicolumn{2}{|c|}{ With Trend } \\
\hline & Statistic & P_Value & Statistic & P_Value \\
\hline GHG_DIFF & -3.454 & $0.000^{* * *}$ & -3.959 & $0.000^{* * *}$ \\
\hline ET_REV & -3.997 & $0.000^{* * *}$ & -6.548 & $0.000^{* * *}$ \\
\hline OTHER_REV & -3.855 & $0.000^{* * *}$ & -6.318 & $0.000^{* * *}$ \\
\hline ET_RATE & -8.631 & $0.000^{* * *}$ & -7.868 & $0.000^{* * *}$ \\
\hline ENV_EXP & -4.468 & $0.000^{* * *}$ & -6.180 & $0.000^{* * *}$ \\
\hline GS_EXP & -0.605 & 0.272 & -1.466 & $0.071^{*}$ \\
\hline SC_EXP & -6.727 & $0.000^{* * *}$ & 5.456 & $0.000^{* * *}$ \\
\hline DEBT & -7.541 & $0.000^{* * *}$ & -2.332 & $0.009^{* * *}$ \\
\hline logENERGY_INT & -5.464 & $0.000^{* * *}$ & -9.284 & $0.000^{* * *}$ \\
\hline ENERGY_DEP & -2.584 & $0.004^{* * *}$ & -3.190 & $0.000^{* * *}$ \\
\hline G_GDP_PC & -9.946 & $0.000^{* * *}$ & -9.224 & $0.000^{* * *}$ \\
\hline logGDP_PC & -2.924 & $0.001^{* * *}$ & -5.971 & $0.000^{* * *}$ \\
\hline MAR_TAXX & -1.899 & $0.028^{* *}$ & -5.699 & $0.000^{* * *}$ \\
\hline VA_IND & -6.613 & $0.000^{* * *}$ & -5.289 & $0.000^{* * *}$ \\
\hline RLE & $-2 ; 367$ & $0.009^{* * *}$ & -2.096 & $0.018^{* *}$ \\
\hline
\end{tabular}

Table A2. Tests of the strict Pigouvian hypothesis.

\begin{tabular}{|c|c|c|c|c|c|c|}
\hline & (1) & (2) & (3) & (4) & (5) & (6) \\
\hline VARIABLES & GHG_DIFF & GHG_DIFF & GHG_DIFF & GHG_DIFF & GHG_DIFF & GHG_DIFF \\
\hline Method & GMM & GMM & Within & GMM & GMM & Within \\
\hline $\mathrm{GHG}_{-} \mathrm{DIFF} \mathrm{t}_{\mathrm{t}-1}$ & $\begin{array}{c}0.3877^{* * *} \\
(0.1118)\end{array}$ & $\begin{array}{c}0.2922^{* * *} \\
(0.0239)\end{array}$ & $\begin{array}{c}0.5937^{* * * *} \\
(0.0529)\end{array}$ & $\begin{array}{c}0.4768^{* * *} \\
(0.0526)\end{array}$ & $\begin{array}{c}0.3429^{* * * *} \\
(0.0349)\end{array}$ & $\begin{array}{c}0.6205^{* * *} \\
(0.0460)\end{array}$ \\
\hline ET_REV & $\begin{array}{l}-0.0009 \\
(0.0108)\end{array}$ & & & $\begin{array}{l}-0.0119 \\
(0.0092)\end{array}$ & & \\
\hline ET_RATE & $\begin{array}{c}0.0005^{* * *} \\
(0.0002)\end{array}$ & $\begin{array}{c}0.0006^{* * *} \\
(0.0001)\end{array}$ & $\begin{array}{c}0.0005^{* * * *} \\
(0.0001)\end{array}$ & $\begin{array}{c}0.0007^{* * *} \\
(0.0001)\end{array}$ & $\begin{array}{c}0.0006^{* * *} \\
(0.0001)\end{array}$ & $\begin{array}{c}0.0006^{* * * *} \\
(0.0001)\end{array}$ \\
\hline G_GDP_PC & $\begin{array}{c}-0.0021^{* *} \\
(0.0008)\end{array}$ & $\begin{array}{c}-0.0026^{* * *} \\
(0.0002)\end{array}$ & $\begin{array}{c}-0.0028^{* *} \\
(0.0013)\end{array}$ & $\begin{array}{c}-0.0022^{* * *} \\
(0.0005)\end{array}$ & $\begin{array}{c}-0.0030^{* * *} \\
(0.0004)\end{array}$ & $\begin{array}{c}-0.0028^{* *} \\
(0.0012)\end{array}$ \\
\hline logGDP_PC & $\begin{array}{c}4.8135 \\
(4.3878)\end{array}$ & $\begin{array}{c}-0.6739 * * * \\
(0.0316)\end{array}$ & $\begin{array}{c}-0.3597^{* * *} \\
(0.0627)\end{array}$ & $\begin{array}{c}1.7303 \\
(3.2731)\end{array}$ & $\begin{array}{c}-0.5141^{* * *} \\
(0.0365)\end{array}$ & $\begin{array}{c}-0.3042^{* * *} \\
(0.0525)\end{array}$ \\
\hline logGDP_PC2 & $\begin{array}{l}-0.2631 \\
(0.2148)\end{array}$ & & & $\begin{array}{l}-0.1095 \\
(0.1604)\end{array}$ & & \\
\hline logENERGY_INT & $\begin{array}{c}-0.1570^{* *} \\
(0.0699)\end{array}$ & $\begin{array}{c}-0.2150^{* * *} \\
(0.0193)\end{array}$ & $\begin{array}{c}-0.0929^{*} \\
(0.0535)\end{array}$ & & & \\
\hline ENERGY_DEP & & & & $\begin{array}{c}-0.0012^{* * *} \\
(0.0004)\end{array}$ & $\begin{array}{l}-0.0001 \\
(0.0002)\end{array}$ & $\begin{array}{l}-0.0003 \\
(0.0005)\end{array}$ \\
\hline VA_IND & $\begin{array}{c}0.0113^{* * *} \\
(0.0029)\end{array}$ & $\begin{array}{c}0.0124^{* * *} \\
(0.0013)\end{array}$ & $\begin{array}{c}0.0050^{* * *} \\
(0.0015)\end{array}$ & $\begin{array}{c}0.0107^{* * *} \\
(0.0021)\end{array}$ & $\begin{array}{c}0.0122^{* * *} \\
(0.0013)\end{array}$ & $\begin{array}{c}0.0055^{* * *} \\
(0.0014)\end{array}$ \\
\hline RLE & $\begin{array}{l}-0.0151 \\
(0.0288)\end{array}$ & $\begin{array}{c}0.0306^{* * *} \\
(0.0105)\end{array}$ & $\begin{array}{c}0.0169 \\
(0.0165)\end{array}$ & $\begin{array}{c}0.0265 \\
(0.0359)\end{array}$ & $\begin{array}{c}0.0635^{* * *} \\
(0.0116)\end{array}$ & $\begin{array}{l}0.0293^{*} \\
(0.0160)\end{array}$ \\
\hline TREND & $\begin{array}{c}0.0072^{* * *} \\
(0.0013)\end{array}$ & $\begin{array}{c}0.0074^{* * *} \\
(0.0008)\end{array}$ & $\begin{array}{l}0.0044^{* *} \\
(0.0018)\end{array}$ & $\begin{array}{c}0.0104^{* * *} \\
(0.0007)\end{array}$ & $\begin{array}{c}0.0120^{* * *} \\
(0.0006)\end{array}$ & $\begin{array}{c}0.0068^{* * * *} \\
(0.0011)\end{array}$ \\
\hline Constant & $\begin{array}{l}-21.0660 \\
(22.4496)\end{array}$ & $\begin{array}{c}7.7637^{* * * *} \\
(0.3915)\end{array}$ & $\begin{array}{c}4.0607^{* * * *} \\
(0.8063)\end{array}$ & $\begin{array}{c}-6.3097 \\
(16.6662)\end{array}$ & $\begin{array}{c}4.9592^{* * *} \\
(0.3660)\end{array}$ & $\begin{array}{c}2.9932^{* * *} \\
(0.5305)\end{array}$ \\
\hline $\begin{array}{l}\text { Observations } \\
\mathrm{R}^{2}\end{array}$ & 308 & 308 & $\begin{array}{c}336 \\
0.7609\end{array}$ & 308 & 308 & $\begin{array}{c}336 \\
0.7567\end{array}$ \\
\hline Number of id & 28 & 28 & 28 & 28 & 28 & 28 \\
\hline AR1 $p$ value & 0.009 & 0.010 & & 0.0002 & 0.0007 & \\
\hline AR2 $p$ value & 0.277 & 0.229 & & 0.418 & 0.278 & \\
\hline $\begin{array}{l}\text { Sargan test } \\
\text { p value }\end{array}$ & 1.00 & 1.00 & & 1.00 & 1.00 & \\
\hline
\end{tabular}


Table A3. Tests of the broad Pigouvian hypothesis.

\begin{tabular}{|c|c|c|c|c|c|c|c|c|}
\hline & (1) & (2) & (3) & (4) & (5) & (6) & (7) & (8) \\
\hline VARIABLES & ENV_EXP & ENV_EXP & ENV_EXP & ENV_EXP & ENV_EXP & ENV_EXP & ENV_EXP & ENV_EXP \\
\hline Method & GMM & GMM & GMM & Within & GMM & GMM & GMM & Within \\
\hline ENV_EXP $_{\mathrm{t}-1}$ & $\begin{array}{c}0.4349^{* * *} \\
(0.0209)\end{array}$ & $\begin{array}{c}0.4509^{* * *} \\
(0.0163)\end{array}$ & $\begin{array}{c}0.4196^{* * *} \\
(0.0212)\end{array}$ & $\begin{array}{c}0.4250^{* * * *} \\
(0.0635)\end{array}$ & $\begin{array}{c}0.2624^{* * *} \\
(0.0855)\end{array}$ & $\begin{array}{c}0.3512^{* * * *} \\
(0.0591)\end{array}$ & $\begin{array}{c}0.3224^{* * * *} \\
(0.0508)\end{array}$ & $\begin{array}{c}0.4276^{* * *} \\
(0.0661)\end{array}$ \\
\hline ET_REV & $\begin{array}{c}-0.0048 \\
(0.0101)\end{array}$ & $\begin{array}{l}-0.0093 \\
(0.0090)\end{array}$ & $\begin{array}{l}-0.0114 \\
(0.0074)\end{array}$ & $\begin{array}{c}0.0045 \\
(0.0125)\end{array}$ & & & & \\
\hline DEBT & & & & & $\begin{array}{c}0.0038^{* *} \\
(0.0018)\end{array}$ & $\begin{array}{l}0.0035^{*} \\
(0.0019)\end{array}$ & $\begin{array}{c}0.0022 \\
(0.0018)\end{array}$ & $\begin{array}{l}-0.0006 \\
(0.0016)\end{array}$ \\
\hline OTHER_REV & & & & & $\begin{array}{l}-0.0071 \\
(0.0088)\end{array}$ & & & \\
\hline G_GDP_PC & $\begin{array}{c}-0.0049^{* * *} \\
(0.0014)\end{array}$ & $\begin{array}{c}-0.0035^{* * *} \\
(0.0010)\end{array}$ & $\begin{array}{c}-0.0036^{* * *} \\
(0.0008)\end{array}$ & $\begin{array}{l}-0.0019 \\
(0.0050)\end{array}$ & $\begin{array}{c}-0.0047^{* * *} \\
(0.0018)\end{array}$ & $\begin{array}{c}-0.0048^{* * *} \\
(0.0018)\end{array}$ & $\begin{array}{l}-0.0022 \\
(0.0015)\end{array}$ & $\begin{array}{l}-0.0016 \\
(0.0051)\end{array}$ \\
\hline logGDP_PC & $\begin{array}{c}6.0185 \\
(8.7120)\end{array}$ & $\begin{array}{c}-0.6111^{* * *} \\
(0.0899)\end{array}$ & $\begin{array}{c}-0.4844^{* * *} \\
(0.0900)\end{array}$ & $\begin{array}{c}-0.5695^{* *} \\
(0.2748)\end{array}$ & $\begin{array}{l}-11.4588 \\
(11.7258)\end{array}$ & $\begin{array}{c}-0.3392 \\
(0.2985)\end{array}$ & $\begin{array}{l}-0.4961 \\
(0.3564)\end{array}$ & $\begin{array}{l}-0.6551 \\
(0.3939)\end{array}$ \\
\hline logGDP_PC2 & $\begin{array}{l}-0.3163 \\
(0.4225)\end{array}$ & & & & $\begin{array}{c}0.5471 \\
(0.5752)\end{array}$ & & & \\
\hline logENERGY_INT & $\begin{array}{c}-0.4459^{* * *} \\
(0.1284)\end{array}$ & $\begin{array}{c}-0.4074^{* * *} \\
(0.1256)\end{array}$ & & & $\begin{array}{l}-0.3377 \\
(0.2108)\end{array}$ & $\begin{array}{l}-0.1546 \\
(0.1241)\end{array}$ & & \\
\hline ENERGY_DEP & & & $\begin{array}{c}-0.0028^{* * *} \\
(0.0008)\end{array}$ & $\begin{array}{l}-0.0011 \\
(0.0016)\end{array}$ & & & $\begin{array}{l}-0.0004 \\
(0.0016)\end{array}$ & $\begin{array}{l}-0.0013 \\
(0.0017)\end{array}$ \\
\hline VA_INDUS & $\begin{array}{c}0.0089^{* *} \\
(0.0040)\end{array}$ & $\begin{array}{c}0.0087^{* * *} \\
(0.0028)\end{array}$ & $\begin{array}{c}0.0091^{* * *} \\
(0.0026)\end{array}$ & $\begin{array}{c}0.0058 \\
(0.0059)\end{array}$ & $\begin{array}{c}0.0008 \\
(0.0169)\end{array}$ & $\begin{array}{l}0.0196^{*} \\
(0.0107)\end{array}$ & $\begin{array}{c}0.0129 * * * \\
(0.0040)\end{array}$ & $\begin{array}{c}0.0056 \\
(0.0062)\end{array}$ \\
\hline RLE & $\begin{array}{c}0.0491 \\
(0.0874)\end{array}$ & $\begin{array}{l}0.1297^{* *} \\
(0.0543)\end{array}$ & $\begin{array}{c}0.2084^{* * *} \\
(0.0502)\end{array}$ & $\begin{array}{c}0.0148 \\
(0.0819)\end{array}$ & $\begin{array}{c}0.0894 \\
(0.1551)\end{array}$ & $\begin{array}{l}-0.0136 \\
(0.0907)\end{array}$ & $\begin{array}{l}-0.0749 \\
(0.0719)\end{array}$ & $\begin{array}{c}0.0234 \\
(0.0879)\end{array}$ \\
\hline TREND & $\begin{array}{c}-0.0154^{* * *} \\
(0.0039)\end{array}$ & $\begin{array}{c}-0.0109^{* *} \\
(0.0049)\end{array}$ & $\begin{array}{c}0.0003 \\
(0.0023)\end{array}$ & $\begin{array}{l}-0.0006 \\
(0.0038)\end{array}$ & $\begin{array}{c}-0.0197^{*} \\
(0.0116)\end{array}$ & $\begin{array}{c}-0.0106^{*} \\
(0.0061)\end{array}$ & $\begin{array}{l}-0.0041 \\
(0.0068)\end{array}$ & $\begin{array}{c}0.0018 \\
(0.0067)\end{array}$ \\
\hline Constant & $\begin{array}{l}-25.8416 \\
(44.7854)\end{array}$ & $\begin{array}{c}8.5480^{* * *} \\
(1.1164)\end{array}$ & $\begin{array}{c}5.2076^{* * *} \\
(0.8445)\end{array}$ & $\begin{array}{c}6.2292^{* *} \\
(2.7685)\end{array}$ & $\begin{array}{c}62.1932 \\
(60.0209)\end{array}$ & $\begin{array}{c}4.1965 \\
(3.6173)\end{array}$ & $\begin{array}{c}5.3434 \\
(3.7522)\end{array}$ & $\begin{array}{l}7.1758^{*} \\
(4.0882)\end{array}$ \\
\hline Observations & 308 & 308 & 308 & 336 & 308 & 308 & 308 & 336 \\
\hline $\begin{array}{l}\text { Number of id } \\
\text { R-squared }\end{array}$ & 28 & 28 & 28 & $\begin{array}{c}28 \\
0.29\end{array}$ & 28 & 28 & 28 & $\begin{array}{c}28 \\
0.29\end{array}$ \\
\hline AR1-pval & 0.007 & 0.005 & 0.006 & , & 0.06 & 0.02 & 0.02 & , \\
\hline AR2-pval & 0.269 & 0.27 & 0.25 & & 0.22 & 0.23 & 0.22 & \\
\hline sargan-pval & 1.00 & 1.00 & 1.00 & & 1.00 & 1.00 & 1.00 & \\
\hline
\end{tabular}

GMM refers toArellano-Bond dynamic panel-data estimation, in (5), (6) and (7) variable DEBT is assumed to be endogenous. Standard errors in parentheses. ${ }^{* *}$ $p<0.01,{ }^{* *} p<0.05,{ }^{*} p<0.1$ 
Table A4. Tests of the 'double dividend' hypothesis.

\begin{tabular}{|c|c|c|c|c|}
\hline & (1) & (2) & (3) & (4) \\
\hline \multirow[t]{2}{*}{ VARIABLES } & ET_REV & ET_REV & ET_REV & ET_REV \\
\hline & GMM & GMM & Within & Within \\
\hline \multirow[t]{2}{*}{ ET_REV } & $0.6596^{* * *}$ & $0.6540^{* * *}$ & $0.8321^{* * *}$ & $0.8281^{* * *}$ \\
\hline & $(0.1233)$ & $(0.1203)$ & $(0.0449)$ & $(0.0426)$ \\
\hline \multirow[t]{2}{*}{ MAR_TAX } & $-0.0373^{* *}$ & $-0.0386^{* *}$ & $-0.0141^{*}$ & $-0.0138^{*}$ \\
\hline & $(0.0180)$ & $(0.0172)$ & $(0.0073)$ & $(0.0073)$ \\
\hline \multirow[t]{2}{*}{ DEBT } & $0.0090^{* *}$ & $0.0086^{* *}$ & $0.0068^{* *}$ & $0.0067^{* *}$ \\
\hline & $(0.0038)$ & $(0.0035)$ & $(0.0027)$ & $(0.0026)$ \\
\hline \multirow[t]{2}{*}{ G_GDP_PC } & $-0.0259^{* * *}$ & $-0.0250^{* * *}$ & $-0.0373^{* * *}$ & $-0.0376^{* * *}$ \\
\hline & $(0.0072)$ & $(0.0055)$ & $(0.0127)$ & $(0.0128)$ \\
\hline \multirow[t]{2}{*}{ logGDP_PC } & -18.8319 & -2.1224 & -8.9629 & -1.0230 \\
\hline & (39.4684) & $(1.3130)$ & (8.7528) & $(0.6773)$ \\
\hline \multirow[t]{2}{*}{ logGDP_PC2 } & 0.8130 & & 0.3901 & \\
\hline & (1.9165) & & $(0.4358)$ & \\
\hline \multirow[t]{2}{*}{ VA_IND } & 0.0298 & 0.0402 & 0.0247 & 0.0342 \\
\hline & $(0.0284)$ & $(0.0266)$ & $(0.0249)$ & $(0.0235)$ \\
\hline \multirow[t]{2}{*}{ RLE } & -0.2849 & -0.2894 & 0.3005 & 0.2772 \\
\hline & $(0.3436)$ & $(0.3324)$ & $(0.2328)$ & $(0.2310)$ \\
\hline \multirow[t]{2}{*}{ TREND } & 0.0087 & 0.0133 & 0.0071 & 0.0099 \\
\hline & $(0.0209)$ & $(0.0186)$ & $(0.0163)$ & $(0.0155)$ \\
\hline \multirow[t]{2}{*}{ Constant } & 110.8605 & $24.9671^{*}$ & 51.3302 & 10.8057 \\
\hline & (203.0291) & (13.6174) & (44.1810) & (6.4779) \\
\hline Observations & 253 & 253 & 276 & 276 \\
\hline Number of id & 23 & 23 & 23 & 23 \\
\hline$R^{2}$ & & & 0.7871 & 0.7867 \\
\hline AR1 $p$ value & 0.006 & 0.007 & & \\
\hline AR2 $p$ value & 0.74 & 0.83 & & \\
\hline Sargan test $p$ value & 1.00 & 1.00 & & \\
\hline
\end{tabular}

Table A5. Tests of the Leviathan hypothesis. Dependent variable: General Services Expenditures (GS_EXP).

\begin{tabular}{|c|c|c|c|c|}
\hline & (1) & (2) & (3) & (4) \\
\hline VARIABLES & GS_EXP & GS_EXP & GS_EXP & GS_EXP \\
\hline & GMM & Within & GMM & Within \\
\hline$G S \_E X P_{t-1}$ & $\begin{array}{c}0.5994^{* * * *} \\
(0.0298)\end{array}$ & $\begin{array}{c}0.5995^{* * * *} \\
(0.0874)\end{array}$ & $\begin{array}{c}0.4808^{* * * *} \\
(0.0395)\end{array}$ & $\begin{array}{c}0.4681^{* * * *} \\
(0.0830)\end{array}$ \\
\hline ET_REV & $\begin{array}{c}0.0221 \\
(0.0280)\end{array}$ & $\begin{array}{l}-0.0369 \\
(0.0570)\end{array}$ & & \\
\hline DEBT & & & $\begin{array}{c}0.0296 * * * \\
(0.0028)\end{array}$ & $\begin{array}{c}0.0188^{* * *} \\
(0.0056)\end{array}$ \\
\hline OTHER_REV & & & $\begin{array}{c}-0.0141 \\
(0.0241)\end{array}$ & $\begin{array}{l}-0.0140 \\
(0.0442)\end{array}$ \\
\hline G_GDP_PC & $\begin{array}{c}-0.0385^{* * *} \\
(0.0050)\end{array}$ & $\begin{array}{c}-0.0295^{* * *} \\
(0.0064)\end{array}$ & $\begin{array}{c}-0.0338^{* * *} \\
(0.0100)\end{array}$ & $\begin{array}{c}-0.0309^{* * * *} \\
(0.0072)\end{array}$ \\
\hline logGDP_PC & $\begin{array}{c}26.1615 \\
(26.3997)\end{array}$ & $\begin{array}{c}0.1190 \\
(12.2934)\end{array}$ & $\begin{array}{c}44.9337 \\
(51.2076)\end{array}$ & $\begin{array}{l}-11.2147 \\
(17.9560)\end{array}$ \\
\hline logGDP_PC2 & $\begin{array}{l}-1.3543 \\
(1.2981)\end{array}$ & & $\begin{array}{l}-2.0885 \\
(2.5329)\end{array}$ & $\begin{array}{c}0.5979 \\
(0.8994)\end{array}$ \\
\hline VA_IND & $\begin{array}{c}0.0078 \\
(0.0184)\end{array}$ & & $\begin{array}{l}-0.0227 \\
(0.1006)\end{array}$ & $\begin{array}{l}-0.0412 \\
(0.0277)\end{array}$ \\
\hline RLE & $\begin{array}{c}0.8116^{* *} \\
(0.3509)\end{array}$ & $\begin{array}{l}1.0249^{* *} \\
(0.4341)\end{array}$ & $\begin{array}{c}0.2941 \\
(0.5144)\end{array}$ & $\begin{array}{l}1.1205^{* *} \\
(0.5248)\end{array}$ \\
\hline TREND & $\begin{array}{c}-0.0167^{* *} \\
(0.0073)\end{array}$ & $\begin{array}{l}-0.0241 \\
(0.0150)\end{array}$ & $\begin{array}{c}-0.1308^{* * *} \\
(0.0387)\end{array}$ & $\begin{array}{c}-0.0932^{* * *} \\
(0.0254)\end{array}$ \\
\hline Constant & $\begin{array}{l}-124.0233 \\
(134.3966)\end{array}$ & $\begin{array}{c}6.6182 \\
(63.2624)\end{array}$ & $\begin{array}{l}-238.1910 \\
(260.7118)\end{array}$ & $\begin{array}{c}55.0385 \\
(88.8045)\end{array}$ \\
\hline Observations & 308 & 336 & 308 & 336 \\
\hline Number of id & 28 & & 28 & \\
\hline$R^{2}$ & & 0.4792 & & 0.5270 \\
\hline AR1 $p$ value & 0.05 & & 0.05 & \\
\hline AR2 $\mathrm{p}$ value & 0.42 & & 0.41 & \\
\hline Sargan test $p$ value & 1.00 & & 1.00 & \\
\hline
\end{tabular}


Table A6. Tests of the Leviathan hypothesis. Dependent variable: Social Protection Expenditures (SC_EXP).

\begin{tabular}{|c|c|c|c|c|}
\hline \multirow[b]{2}{*}{ VARIABLES } & (1) & (2) & (3) & (4) \\
\hline & SC_EXP & SC_EXP & SC_EXP & SC_EXP \\
\hline \multirow{3}{*}{ SC_EXP } & GMM & Within & GMM & Within \\
\hline & $0.5637^{* * *}$ & $0.6453^{* * *}$ & $0.5634^{* * *}$ & $0.6496^{* * *}$ \\
\hline & $(0.0328)$ & $(0.0422)$ & $(0.0492)$ & $(0.0447)$ \\
\hline \multirow[t]{2}{*}{ ET_REV } & 0.0238 & -0.0276 & & \\
\hline & $(0.0578)$ & $(0.0526)$ & & \\
\hline DEBT & & & $\begin{array}{c}-0.0218^{* * *} \\
(0.0057)\end{array}$ & $\begin{array}{l}-0.0027 \\
(0.0046)\end{array}$ \\
\hline OTHER_REV & & & $\begin{array}{c}-0.1347^{* * *} \\
(0.0371)\end{array}$ & $\begin{array}{c}0.0013 \\
(0.0333)\end{array}$ \\
\hline G_GDP_PC & $\begin{array}{c}-0.1575^{* * *} \\
(0.0088)\end{array}$ & $\begin{array}{c}-0.1629 * * * \\
(0.0071)\end{array}$ & $\begin{array}{c}-0.1422^{* * *} \\
(0.0096)\end{array}$ & $\begin{array}{c}-0.1628^{* * *} \\
(0.0072)\end{array}$ \\
\hline logGDP_PC & $\begin{array}{l}49.1363^{*} \\
(26.8805)\end{array}$ & $\begin{array}{c}25.2546 \\
(15.9450)\end{array}$ & $\begin{array}{c}81.4676^{* * * *} \\
(21.5474)\end{array}$ & $\begin{array}{c}24.3807 \\
(15.2027)\end{array}$ \\
\hline logGDP_PC2 & $\begin{array}{c}-2.5445^{*} \\
(1.3008)\end{array}$ & $\begin{array}{c}-1.3714^{*} \\
(0.7948)\end{array}$ & $\begin{array}{c}-4.2949 * * * \\
(1.0781)\end{array}$ & $\begin{array}{l}-1.3363^{*} \\
(0.7506)\end{array}$ \\
\hline VA_IND & $\begin{array}{c}-0.0694^{* * *} \\
(0.0210)\end{array}$ & $\begin{array}{l}-0.0438 \\
(0.0304)\end{array}$ & $\begin{array}{l}-0.0384 \\
(0.0264)\end{array}$ & $\begin{array}{l}-0.0451 \\
(0.0304)\end{array}$ \\
\hline RLE & $\begin{array}{c}0.0877 \\
(0.2706)\end{array}$ & $\begin{array}{c}0.3167 \\
(0.3817)\end{array}$ & $\begin{array}{c}0.0408 \\
(0.4682)\end{array}$ & $\begin{array}{c}0.3262 \\
(0.3892)\end{array}$ \\
\hline TREND & $\begin{array}{c}0.0424^{* * *} \\
(0.0088)\end{array}$ & $\begin{array}{l}0.0332^{* *} \\
(0.0156)\end{array}$ & $\begin{array}{c}0.1442^{* * * *} \\
(0.0311)\end{array}$ & $\begin{array}{l}0.0406^{*} \\
(0.0238)\end{array}$ \\
\hline Constant & $\begin{array}{l}-227.1325 \\
(139.5503)\end{array}$ & $\begin{array}{c}-107.4301 \\
(79.4353)\end{array}$ & $\begin{array}{c}-369.5987^{* * *} \\
(106.9613)\end{array}$ & $\begin{array}{c}-102.3305 \\
(76.6965)\end{array}$ \\
\hline Observations & 308 & 336 & 308 & 336 \\
\hline Number of id & 28 & & 28 & \\
\hline $\mathrm{R}^{2}$ & & 0.8971 & & 0.8972 \\
\hline AR1 $p$ value & 0.001 & & 0.003 & 0.003 \\
\hline AR2 p value & 0.02 & & 0.13 & 0.13 \\
\hline Sargan test $p$ value & 1.00 & & 1.00 & 1.00 \\
\hline
\end{tabular}

GMM refers to Arellano-Bond dynamic panel-data estimation, in (3) variable DEBT is assumed to be endogenous. Standard errors in parentheses. ${ }^{* *} p<0.01,{ }^{* *} p<0.05,{ }^{*} p<0.1$ 